\title{
Texts from the Winter Feasts of the Kalasha of Birir
}

\author{
Augusto S. Cacopardo \\ Firenze
}

\begin{abstract}
The author presents a collection of texts recorded in 2006-07 during the winter ritual cycle of the Kalasha of the Birir valley - in NorthWest Pakistan - who still practice an archaic form of polytheism with pre-Vedic roots. The fulcrum of the cycle is the Chaumos Winter Solstice Festival, but a number of other festivities follow it at intervals forming a sequence almost two months long, lasting until February. The selection includes texts of songs, chants or prayers from each of these festivities. To allow the reader to relate them to the context in which they were recorded, the texts are accompanied by explanatory ethnographic notes. An introduction sketches the broader scene in which the research was carried out. The texts are in the Birir dialect of Kalashamon, the language of the Kalasha, a North-West-Indo-Aryan, or Dardic, language.
\end{abstract}

Keywords: Hindu Kush, Kafir, Kalasha, language, Pakistan, polytheism, religion, texts, New Year festival.

The objective of this article is to present a number of texts recorded by the author between December 2006 and early February 2007, during the winter ritual cycle of the Kalasha community of Birir, which 
culminates in the Chaumos Winter Solstice Festival. The Kalasha are a small minority group that lives in three valleys - Bumburet, Rumbur and Birir - located in the south of the district of Chitral, in the NorthWest-Frontier-Province of Pakistan. Numbering only a few thousands, they speak an Indo-Aryan language of the North-West-Indo-Aryan (Dardic) (Bashir 2003) group called Kalashamon (Morgenstierne 1973; Bashir 1988; Trail \& Cooper 1999; Heegård 2006; Di Carlo 2009), and they are the last polytheists of the Hindu Kush ${ }^{1}$. Their religion is the last example of a multifarious constellation of archaic polytheisms that still at the beginning of the nineteenth century were widely practiced throughout the Hindu Kush/Karakorum chain, from present-day Afghan Nuristan to western Ladakh. In the two following centuries the advance of Islam, that had made inroads in the area since the sixteenth century, gradually brought about the conversion of these communities of mountaineers ${ }^{2}$ with the sole exception of the three Kalasha communities who, though partially converted, still practice their traditional religion to this day.

The religion of the Kalasha has long attracted the attention of scholars not only because it is the only surviving shred of the preIslamic cultural fabric of the Hindu Kush, but also because it is the only living example of what we may call a "tribal" Indo-European religion, that is a religious system practiced by speakers of an IndoEuropean language, which has not been absorbed by any one of the great historic systems, Buddhism, Hinduism, Christianity, Islam. Its roots hark back to pre-Vedic times. Morphologically it is a form of polytheism based on a pastoral ideology revolving around a pure/impure ('onjiSTa/pr'agata) polarity that attaches positive values, such as solidarity and harmony with wild nature, to the male sphere of goat-herding, as opposed to the female sphere of agriculture where

1 Recently converted Kalasha communities where Kalashamon is still spoken are found also in the two southern valleys of Jinjeret Kuh (Cacopardo \& Cacopardo 1992, 1996) and Urtsun (Cacopardo, A. S. 1991, 1996; Cacopardo \& Cacopardo 2001: 261-277). Earlier converts, living in various settlements around Drosh and in the Shishi Kuh valley, have abandoned Kalashamon for Khowar (the majority language of Chitral), opting for a radical change of identity (Cacopardo A.M. 1991, 1996; Decker 1992: 96-114; Mørch 2000).

2 For a detailed presentation of the relevant sources see Cacopardo \& Cacopardo 2001: 25-44. 
individual interests and control over nature prevail. Its practice consists essentially in the celebration of the rites composing their complex ritual system. It is an orthopraxic rather than an orthodoxic religion (Bell 1997: 191-197); founded, that is, on the respect of a code of behaviour - mainly ritual - rather than on the adherence to a system of beliefs. ${ }^{3}$

As focus of the rich ritual cycle, the yearly festivals have been studied from the very beginning of ethnographic research among the Kalasha. Of these, the Joshy (zh'oshi) spring festival and the Chaumos (caum'os) winter solstice festival are the most important. ${ }^{4}$ The former was documented by Morgenstierne already in 1929 and then by Schomberg and Siiger in 1935 and 1947 respectively, in Rumbur, and by Loude in 1978 in Bumburet (Schomberg 1938; Morgenstierne 1947; Siiger 1956: 24-26; Loude 1980: 79-90), while the latter was observed for the first time only in 1955 by the German ethnographers Adolf Friedrich and Peter Snoy in the Bumburet valley. The data on Chaumos remained however unavailable to scholars for twenty more years, until they were finally published (but only in German) by Karl Jettmar (1975) in his main work on the pre-Islamic religions of the Hindu Kush. Subsequently, no other researcher participated in a Kalasha winter solstice festival until 1973 when the present author took part in the Chaumos of the Rumbur valley together with Alberto Cacopardo and Manuela Borriello, and the Austrian Karl Wutt participated in the winter festival of Bumburet. The publication of this new data however was also delayed. It appeared only in the '80s (Wutt 1983; Cacopardo, A. S. 1985; Cacopardo \& Cacopardo 1989), when a complete book focussed largely on the Rumbur Chaumos also appeared, authored by the French ethnographers Jean-Yves Loude and Viviane Lièvre (1984) who had begun their fieldwork among the Kalasha in the late '70s. Lastly, a full account of his (and Friedrich's) 1955 observations in Bumburet has recently been published in English

3 For descriptions of Kalasha religion see Jettmar 1975; Witzel 2004; Cacopardo A.S. 2010.

4 Other important cyclic celebrations are the Uchaw late summer festival, especially in Rumbur (Loude \& Lièvre 1987: 193-203) and Bumburet, and the Prun autumn festival in Birir (Staley 1964, 1982: 71-75; Lines 1988: 224-232; Loude \& Lièvre 1987: 204-219; Lièvre \& Loude 1991; Di Carlo 2007). 
in the form of a long essay by Peter Snoy (2008). Thanks to these works we may say that the Chaumos of the two northern valleys is by now fairly well documented.

In contrast, no data at all was available on the winter festival of the southern valley of Birir, until the present author conducted his research there in the winter of 2006-07. The internal cultural variety of the Kalasha had been rather overlooked. Though it had long been quite clear that the southern valley of Birir presented many cultural peculiarities, no thorough study had been conducted of that community until 2006, so that its ritual system was largely unstudied and its main festivals still mostly undocumented. The investigation carried out on the Birir Chaumos showed that the peculiarities are quite remarkable, and that they concern not only single traits but, to some extent, the structure itself of the festival.

Both in Bumburet/Rumbur and in Birir, Chaumos is an extremely complex festival lasting many days and followed by other ritual events composing a sequence that continues well into January. An article on the Birir Chaumos, that includes a comparison with the festival of Bumburet/Rumbur, has already been published by the present author on this same journal (Cacopardo, A. S. 2008). ${ }^{5}$ Since, however, only three texts could be included in that article for reasons of space, this second work has the specific purpose of making available to scholars - both anthropologists and linguists - a larger part of the corpus of prayers, songs, and invocations, that were recorded during the festival.

For all general aspects and for an overall description/ interpretation of the festival, I refer therefore the reader to my previous work, but to allow him to relate, here, the texts to the events in which they were generated, I offer a concise ethnographic comment and analysis of each text, as well as an outline of the whole winter ritual sequence where the main ritual activities are indicated for each day (see Appendix). Apart from making the texts more intelligible, these comments will also give me the opportunity to present some

5 A detailed description and analysis of the Birir Chaumos is now available in Italian (Cacopardo A. S. 2010). 
ethnographic data - especially about the January festivities following Chaumos - which could not be included in my former article. ${ }^{6}$

\section{The Texts}

The texts presented here are only a small part of those recorded, which amount to 28 hours and 29 minutes. A first transcription and rough translation of a part of the materials recorded was done in the field, with the help of a young Kalasha teacher, by the name of Baras Khan, who had a fair command of English, and of some other non-Englishspeaking middle-aged informants - Danok, Erfan (also known as Turap Khan) and Gulistan (also known as Nur Bek) - who were more knowledgeable as to the content of the texts. ${ }^{7}$ The parsing and final interlinear translations were done in Italy with the support of the software Toolbox for linguists. ${ }^{8}$ I present here 17 texts. The majority are chants and songs, but there are also three recited prayers (texts nos. $2,16,17)$, two chanted prayers (texts nos.10,12) and one text of ritual insults (text no.1).

As for the songs, in the Birir Chaumos we can distinguish two categories of songs/dances. There are songs/dances which are heard at all yearly festivals and at social celebrations - like funerals and merit feasts - as well, and there are songs and chants sung only for the winter festival. The first category consists of three genres of verbal art, ca , d'ushak and drazha'ilak. ${ }^{9}$ Of these, I have included only one

6 Linguists will forgive me if I do not offer linguistic comments, but I hope they will find the texts useful as new materials for the study of the still little known dialect of Birir, and of Kalasha ritual language in general.

7 Several other people, too many to list, offered me assistance and warm hospitality. To all I express my gratitude.

8 I want to thank here Pierpaolo Di Carlo, who participated in the Birir project as an ethnolinguist documenting the autumn Prun festival (Di Carlo 2007), for preparing the software and, in general, for his precious support in linguistic matters (only mine of course the responsibility for any faults). The project was part of a research mission funded, partially, by the Istituto Italiano per l'Africa e l'Oriente (Is.I.A.O.) of Rome, and by the University of Florence. A third member of the team was Alberto M. Cacopardo, who conducted ethnohistorical research in Upper Chitral, Swat, Dir and the Bashgal valley.

9 For a detailed description of the three genres see Parkes 1994, 1996; Di Carlo 2007: 63-76, 89-97; Cacopardo A. S. 2010: 160-178. One of the main 
example - a ca - in the selection presented here. The other ten songs in the selection all belong to the second category, which includes songs that appear to stem from the female world, and were sung almost exclusively by the women. I have chosen to present mostly texts of women's songs because they are the ones more specific to Chaumos and are directly connected to the rituals. They may be quite ancient because they were qualified as b'aLuSa ghO , 'old songs', and their lyrics appeared to be common knowledge.

In reading the texts, I advise the reader to note that the first two lines (both in Kalashamon and therefore in bold italics) are, respectively, the text and the morpheme break; the third and the fourth, the English glosses and the free translation. When a verse takes two lines, the sequence, save for the free translation, is doubled. For transcriptions and abbreviations see the note at the end of the article.

\section{Text no. 1}

The ritual insults transcribed below, were recorded on the evening of the third day of Chaumos called goST-s'araz (December $16^{\text {th }}, 2006$ ), during a torchlight procession from the surrounding hamlets to the temple of the village of Guru.

\begin{tabular}{|c|c|c|}
\hline $\begin{array}{l}g^{\prime} u r u h ' O \sim R i \\
g^{\prime} u r u \\
\text { Guru.village }\end{array}$ & $\begin{array}{l}h^{\prime} \mathbf{O} \sim \boldsymbol{R i} \\
\text { inhabitants }\end{array}$ & $\begin{array}{l}\text { zh'awi } \\
\text { zh'aw } \\
\text { fuck }\end{array}$ \\
\hline
\end{tabular}
people of Guru, fuck you!

$\begin{array}{lll}\text { o } & \text { zh'awi } & \\ \text { o } & \text { zh'aw } & -\boldsymbol{i} \\ \text { oh } & \text { fuck } & \text {-IMPV.2S }\end{array}$

differences between the Chaumos of Birir and that of the two northern valleys is that only Chaumos songs and dances are allowed there, while the ordinary songs/dances of the other celebrations are banned, together with the beating of drums that invariably accompanies them. 


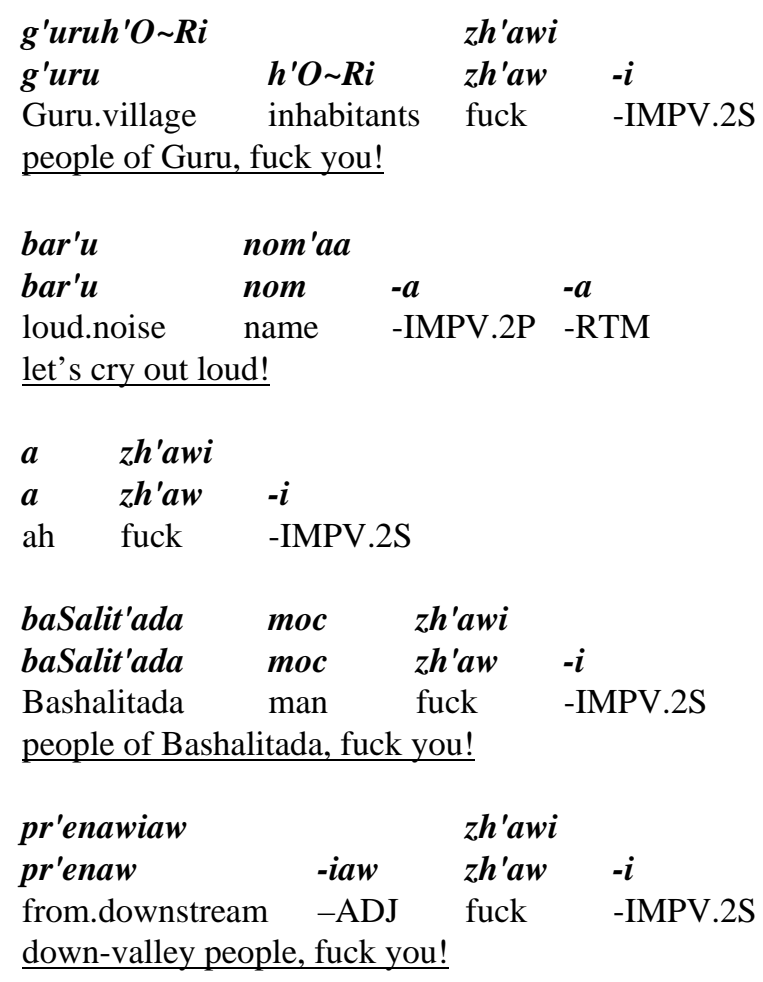

In its last part, the procession took the form of an assault on the temple with the crowd rushing up the hill, whistling and yelling. The insults were cried out mainly (though not exclusively) by the young virgin boys ('onjiSTa s'uda) and by the initiates; i.e. the 'pure' ones were insulting the adults, considered 'impure' because of their sexual contact with women. The insults were at times addressed also to individuals, and especially to respected ones. In a society, like that of the Kalasha, in which the hierarchical principle, apart from gender relations, applies only to the relations between the young and the elder, these insults represent a reversal of roles that is quite typical of New Year celebrations. Such reversals have been seen as a ritual of separation (Van Gennep 1981: 98), in which ordinary social ties are modified and sometimes even severed. On this very day indeed the boys who are to be initiated begin to form a separate group that will 
isolate itself from the village community, together with those who are already initiated but are still virgin ('onjiSTa s'uda).

Text no. 2

As the torchlight procession streamed at a fast pace into the temple, a group of women, gathered under the porch, greeted the assailants with this chant:

$\begin{array}{lllll}\boldsymbol{t} \text { 'ai } & \text { Lucapat'a } & \text { o } & \text { sh'aio } & \\ \text { t'ai } & \text { Lucapat'a } & -o & \text { sh'ai } & \text {-o } \\ \text { 2S.GEN } & \text { lighting.up } & \text {-RTM } & \text { REFRAIN } & \text {-RTM } \\ \text { your light of many torches, shaiooo } & & \end{array}$

\begin{tabular}{llllll} 
b'ira & m'ari & \multicolumn{1}{c}{ Dh'ou } & sh'aio & \\
b'ira & mar & $-\mathbf{i}$ & Dh'ou & sh'ai & -o \\
he.goat & sacrifice & -PRF.P. & heaping & REFRAIN & -RTM \\
the sacrifice of many he-goats, shahiooo &
\end{tabular}

$\begin{array}{lllllll}\text { r'oZHas } & & \text { th'ara } & \text { r'Ozho } & & \text { sh'aio } & \\ \text { roZH } & - \text { as } & \text { thar } & \text { roZH } & - \text { o } & \text { sh'ai } & - \text { o } \\ \text { blessing } & -O B L & \text { on } & \text { blessing } & \text {-RTM } & \text { REFRAIN } & \text {-RTM } \\ \text { blessings upon blessings, shaiooo } & & & & \end{array}$

blessings upon blessings, shaiooo

\begin{tabular}{llllll} 
sh'aio & & t'ai & Lucapat'a & sh'aio & \\
sh'ai & $-o$ & \multicolumn{1}{c}{ 'ai } & Lucapat'a & sh'ai & - o \\
REFRAIN & -RTM & 2S.GEN & lighting.up & REFRAIN & -RTM \\
shaiooo, your light of many torches
\end{tabular}

shaiooo, your light of many torches

$\begin{array}{lllll}\text { sh'ia } & \text { se } & \text { caum'os } & \text { dewasam'E a } \\ \text { sh- } & \text { 'ia } & \text { se } & \text { caum'os } & \text { dewasam'E a } \\ \text { INT- } & \text { PROX.S.NOM } & \text { REM.S.NOM } & \text { Chaumos } & \text { celebration }\end{array}$

this is the Chaumos celebration

With a slow, drawn out, melody sung in unison, the chant was hailing the arrival of the central part of the festival with the torchlight processions, the goat sacrifices, and the many blessings that the rites would bring. The term dewasam'E a in the last verse - which my assistant translated as 'celebration' - is applied only to Chaumos and it implies, I was told, the idea of a descent of a god, a central theme of 
the winter solstice festival, as we shall see in the song that follows. A possible etymology of this term could be d'ewa (god) - sam'E < samana,${ }^{10}$ meeting, reunion: the meeting with the god.

Only women were chanting and no man joined in. I could not obtain any comment on the meaning of the refrain, which is possibly mere harmonizing sound without a referent.

Text no. 3

When the processions reached the temple greeted by the chant of the women gathered under the porch, inside the building the drums were beating and the dancing had already begun.The text transcribed here is only one of the many - the singing and dancing went on until 3 a.m. that were recorded that night. It is a $c a \sim$, a genre that is considered to be a dance (nat) rather than a song ( $g h O \sim$ ). The rhythm is fast and joyful and the dancing prevails indeed over the singing. Of the three genres featured in all Kalasha celebrations, $c a \sim$ is the one that usually expresses the core theme of the event (Di Carlo 2007: 76).

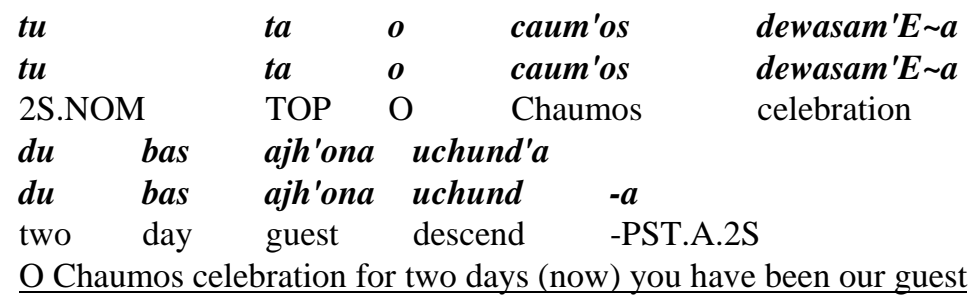

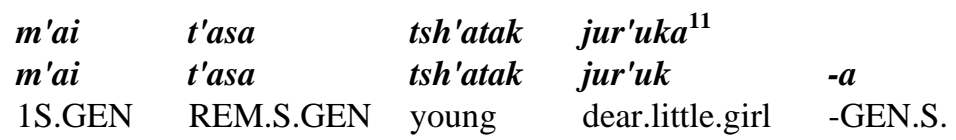

10 Though this proposal is not quite in line with the existing reconstructions of the formation of retroflex vowels in Kalashamon - following the loss of an intervocalic retroflex consonant (Heegård J. and I. E. Mørch 2004; Di Carlo 2010) - it seems nevertheless likely.

11 According to Trail and Cooper (1999: 143) this term, which has an endearing connotation, is used by people other than the parents and those who can address the girl as chu, daughter. 


\section{Sumber'osh}

Sumber'osh

first.celebration

$\underline{\text { my little girl will be initiated }}$

$\begin{array}{llllll}\text { m'ai } & \text { shay'a } & & \text { Dandiagr'om } & \text { s'uda } & \text { tamash'a } \\ \text { m'ai } & \text { sh- } & \text { ay'a } & \text { Dandiagr'om } & \text { s'uda } & \text { tamash'a } \\ \text { 1S.GEN } & \text { INT- } & \text { here } & \text { Guru.(old.name) } & \text { child } & \text { entertainment }\end{array}$

it will be a feast for the children of my village of Guru

\begin{tabular}{lllll} 
dewasam'E a & \multicolumn{2}{l}{ h'awale } & & \\
dewasam'E a & h'aw & -aw & -e \\
celebration & become.PST.A $\quad$-PST.A.3S & -RTM \\
m'ai & neas'alak & h'iu & & \\
m'ai & neas'alak & hi & -u & \\
1S.GEN & regret & become & -P/F.3S
\end{tabular}

when the celebration will be over I shall be sorry

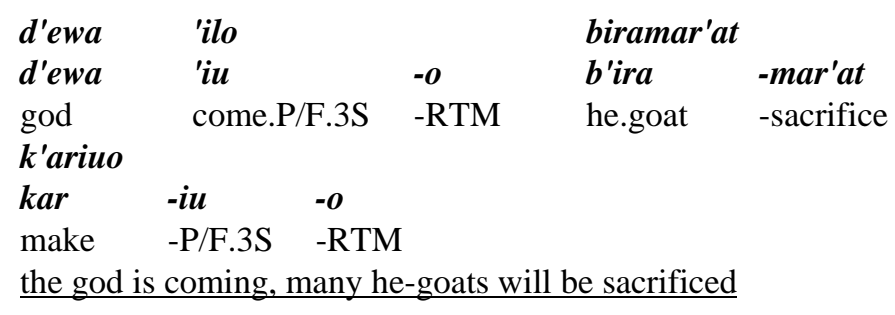

\begin{tabular}{|c|c|c|c|c|c|}
\hline d'ewa & 'ilo & sh'ala & & jur'uka & \\
\hline d'ewa & 'iu & sh & -ala & jur'uk & $-a$ \\
\hline god & come.P/F.3S & INT & -DIST.ACC & dear.little.girl & -GEN \\
\hline \multicolumn{6}{|c|}{ Sumber'osh band'alo } \\
\hline \multicolumn{2}{|c|}{ Sumber'osh } & & $-a u$ & & \\
\hline first.cel & ration & ounce & -P/F.3S & & \\
\hline
\end{tabular}

$\begin{array}{lllllll}\text { d'ewa } & \text { 'ilo } & & \text { sh'asa } & & \text { L'ui } & \text { thum } \\ \text { d'ewa } & \text { 'iu } & -o & \text { sh- } & \text { 'asa } & \text { L'ui } & \text { thum } \\ \text { god } & \text { come.P/F.3S } & \text {-RTM } & \text { INT- } & \text { DIST.S.NOM } & \text { blood } & \text { smoke }\end{array}$




\section{zhe s'aras thum \\ zhe s'aras thum \\ and juniper smoke}

the god is coming, the scent of blood and of juniper (will rise as smoke from the sacrificial fires)

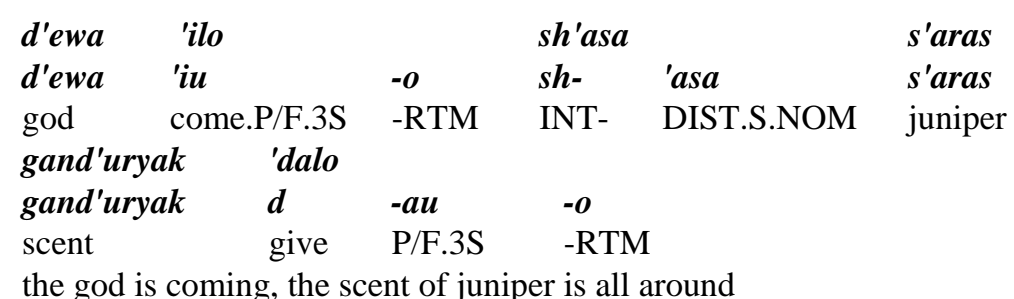

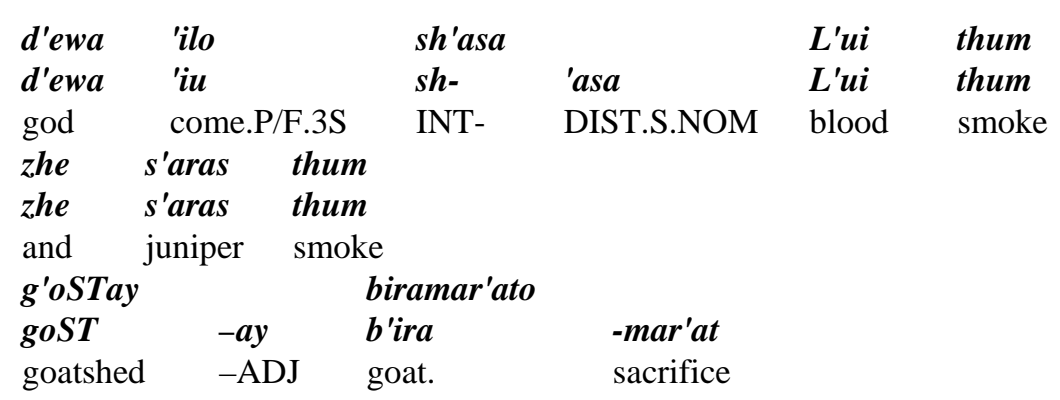

the god is coming, clouds of juniper smoke are rising from the sacrificial fires burning in the goat-sheds

The verses were not sung by a single singer, but were cried out in turns by six singers - all male - who formed in that moment the circle (magl'is) that in a Kalasha celebration directs the singing and the dancing, while the people around plunged themselves in the dance without paying them any attention. The text is composed largely of standard formulas. The first verse welcomes the feast, addressing it as if it were a person. The temporal reference is exact: it was indeed the third day of Chaumos. The other verses, like the women's chant of text no. 2, recall the main events of the festival, the initiations of the girls, the many animal sacrifices for the male initiation ceremonies, and evoke the joyful atmosphere of those days. From the point of view of its contents, the most interesting point of the song is the announcement of the arrival of a divine being; who remains however 
without a name. This, I was told, is a central point in the ideology of Chaumos. That this was the case in Birir as well came rather as a surprise, because the main structural difference between the Chaumos of Birir and that of the two northern valleys was known to be the absence of the cult of the god Balimain who is believed to arrive in Bumburet on a winged horse on the holiest night of the festival. The lyrics of this $c a \sim$ show instead that the idea of the descent of a divine being for the winter solstice is present in Birir as well, though it is not fully ritualized as is the case in the two northern valleys.

Text no. 4

The following day, the fourth of Chaumos, is called non g rat. Since the initiation ceremonies that take place on the fifth day require three he-goats to be killed for each male novice, the sacrifices started already the day before. The meat of the animals sacrificed was going to be offered the following day in a banquet that took place after the ist'on gas initiation rite (Cacopardo A. S. 2008: 90-91). The text below is a prayer that was uttered just before the throat of one of the sacrificial victims was slit by an 'onjiSTa suda, on the roof of a goatshed belonging to the family of one of the novices.

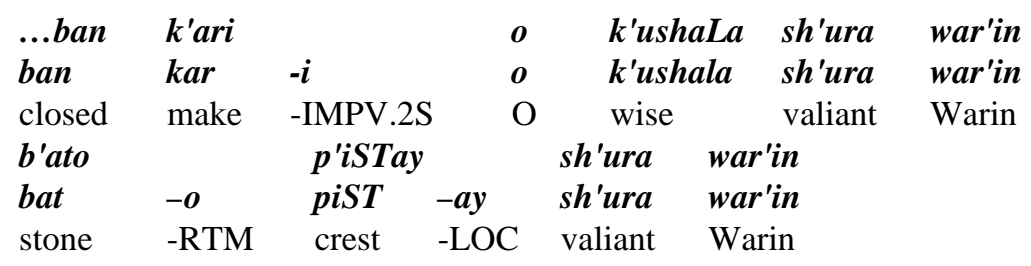

(initial words lost) prevent $\mathrm{O}$ wise and valiant Warin; you, valiant Warin, who dwells among the rocks of the crest

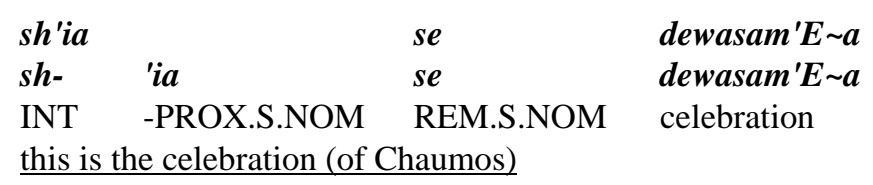

$\begin{array}{lllll}\text { suw'ash } & \text { kay } & \text { aw'icas } & & \boldsymbol{t u} \\ \text { suw'ash } & \text { kay } & \text { aw'ic } & -\boldsymbol{a s} & \boldsymbol{t u} \\ \text { promptly? } & \text { do.CP } & \text { accept } & \text {-P/F.2S } & \text { 2S.NOM }\end{array}$




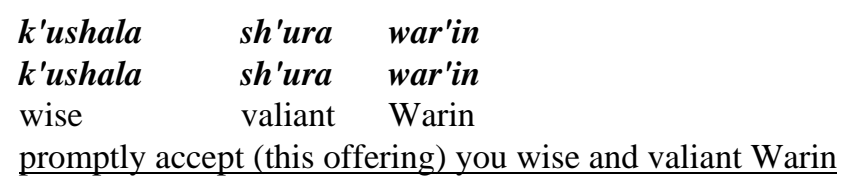

\begin{tabular}{|c|c|c|c|c|c|c|c|}
\hline khayr'i & & $k^{\prime} a r i$ & & bato & & piSTay & \\
\hline khayr & $-i$ & kar & $-i$ & bat & $-O$ & piST & $-a y$ \\
\hline $\begin{array}{l}\text { peace } \\
\text { sh'ura } \\
\text { sh'ura }\end{array}$ & -ADJ & $\begin{array}{l}\text { make } \\
\text { war'in } \\
\text { war'in }\end{array}$ & -IMPV.2S & stone- & RTM & crest & -LOC \\
\hline $\begin{array}{l}\text { valiant } \\
\text { bring pe }\end{array}$ & ace $\mathrm{O}$ & $\begin{array}{l}\text { Warin } \\
\text { valiant V }\end{array}$ & $n$ of the $r$ & crest & & & \\
\hline
\end{tabular}

\begin{tabular}{|c|c|c|c|c|c|c|}
\hline $\begin{array}{l}\boldsymbol{k h} \text { 'ayr } \\
\text { khayr } \\
\text { peace }\end{array}$ & $\begin{array}{l}\text { zhaL'ai } \\
\text { zhaL } \\
\text { arrive }\end{array}$ & $\begin{array}{l}-\boldsymbol{a} \boldsymbol{i} \\
-\mathrm{CP}\end{array}$ & $\begin{array}{l}\text { kim'on } \\
\text { kim'on } \\
\text { much }\end{array}$ & $\begin{array}{l}\text { 'is } \\
\text { 'is } \\
\mathrm{PI}\end{array}$ & $\begin{array}{l}\text { 'isa } \\
\text { 'isa } \\
\text { PROX.2S.OBL }\end{array}$ & $\begin{array}{l}\text { tazag'i } \\
\text { tazag'i } \\
\text { health }\end{array}$ \\
\hline $\begin{array}{l}\text { k'ari } \\
\text { kar } \\
\text { make }\end{array}$ & $\begin{array}{l}-\boldsymbol{i} \\
-I M P V .2 S\end{array}$ & $\begin{array}{l}a b \\
a b \\
\text { off }\end{array}$ & $\begin{array}{l}\text { It } \\
\text { pring }\end{array}$ & $\begin{array}{l}\boldsymbol{k} \text { 'ari } \\
\text { kar } \\
\text { make }\end{array}$ & $\begin{array}{ll}\boldsymbol{i} & \\
& -\mathbf{i} \\
\mathrm{e} & -\mathrm{IMPV} .2 \mathrm{~S}\end{array}$ & \\
\hline
\end{tabular}

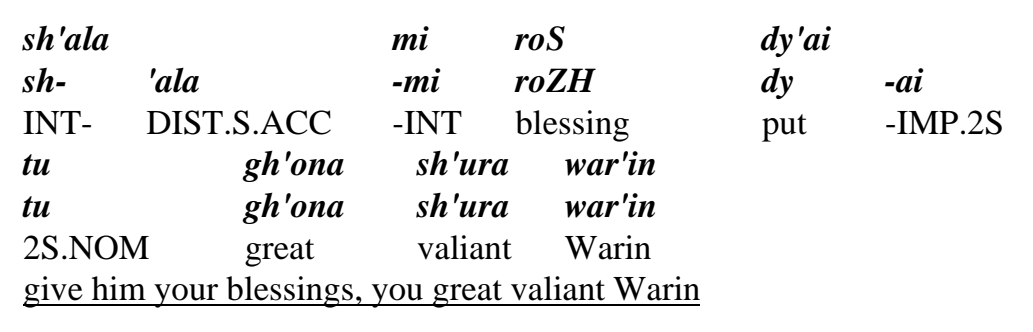

\begin{tabular}{|c|c|c|c|c|c|}
\hline $\begin{array}{l}\text { pak } \\
\text { pak } \\
\text { holy }\end{array}$ & $\begin{array}{l}\text { Parwadig'ar } \\
\text { parwadig'ar } \\
\text { Creator.God }\end{array}$ & & $\begin{array}{l}\text { k'ushaLa } \\
\text { k'ushala } \\
\text { wise }\end{array}$ & $\begin{array}{l}\text { sh'ura } \\
\text { sh'ura } \\
\text { valiant }\end{array}$ & $\begin{array}{l}\text { war'in } \\
\text { war'in } \\
\text { Warin }\end{array}$ \\
\hline khod'aias & & dust & 'asas & & \\
\hline khod'ai & $-a s$ & dust & 'as & $-a s$ & \\
\hline God & -GEN & friend & be & -P/F.2S & \\
\hline
\end{tabular}

you wise and valiant Warin, you who are the friend of the holy Creator God

The prayer is addressed to Warin, one of the main gods of Birir. For Ralph Turner (T-444) the name Warin - war'indras in the genitive - is 
etymologically connected to *a-parendra (unrivalled Indra) and Morgenstierne (1973: 58) relates that one of his informants actually identified Warin with In, Indr. The epithet sh'ura (valiant), traditionally attributed to Warin, seems to indicate that his personality is that of a warrior god, who defends his people from their enemies; $k^{\prime} u s h a L a$ (wise, ingenious), in contrast, is an epithet more frequently attributed to Mahandeo, another important Kalasha divinity who is believed to have taught them important techniques, like that of making cheese. Warin is invoked also as "Warin of the rocky crests" because his shrine, that appears to inspire a sort of 'sacred terror', is located high up on a crest overlooking the lower part of the valley. The requests made in the prayer are quite standard; only that they are made specifically for the novice. The lost initial word was probably a term for sorrow or suffering. The god is asked to avert sorrow from him and to give him peace, health and many children. The last verse is particularly interesting because it shows the evolution undergone by Kalasha polytheism as a consequence of its multi-centennial contact with Islam: as I have discussed more in detail elsewhere (cf. Cacopardo, A. S. 2006: 147-151), a conciliatory version of the traditional religion has probably long prevailed among the Kalasha, which identifies the ancient Creator God Dizala Dezaw (D'iziLa Diz'aw) with the God of Islam. In the light of this reinterpretation the other deities of the traditional pantheon are conceived more as messengers and carriers of wishes to God than divinities in their own right (cf. Saifullah Jan 1996: 240). Yet, the image of the divinity conveyed in the prayer is that of a full-size god able to grant wishes and bestow favour in the circumstances of life; it is only in the last verse that the conciliatory version surfaces with the quite overt statement that Warin's powers are due in the end to his special relation to God.

\section{Text no. 5}

The fifth day of Chaumos (ist'on gas rat) is the day of initiations. For male novices, as soon as the rite is performed (Cacopardo, A. S. 2008: 90 ), a period of seclusion begins that is to last 48 hours, until the last day of the festival. The seclusion consists in the boys being confined in the area of the goat-sheds, which are located above the villages in the holly-oak forest. In the pastoral ideology of the Kalasha, the whole activity of goat-herding and the places where it is conducted are 
'onjiSTa and hence forbidden to women, who have no access to the area of goat-sheds and to the pastures. The song transcribed below recalls the ritual activities carried out by the novices and their peers (the prabal'on g'Uak) during their seclusion, with a reference to the hardships they have to go through. It was recorded on the sixth day (koT SaT'ek) of Chaumos - December $19^{\text {th }}$, in 2006 - on the gri dancing ground, from a group of women.

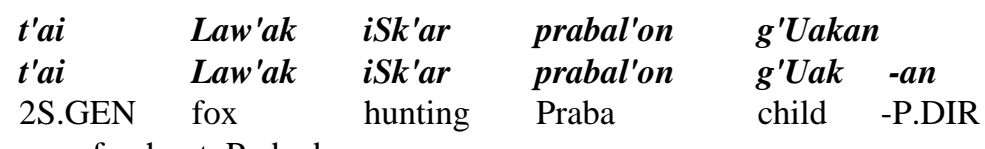

your fox hunt, Praba boys

$\begin{array}{llllll}\text { s'aTuk } & \text { zhe } & \text { kuS'urek } & \text { ciSTuni'aka } & \text { zhus } & \\ \text { s'aTuk } & \text { zhe } & \text { kuS'urek } & \text { ciSTuni'aka } & \text { zhu } & \text {-s } \\ \text { apple-mash } & \text { and } & \text { bread } & \text { standing? } & \text { eat } & \text {-P/F.2S }\end{array}$

you cannot sit down to eat your bread and apple-mash

\begin{tabular}{|c|c|c|c|c|c|}
\hline \multicolumn{6}{|c|}{ iCh'oae } \\
\hline$t^{\prime} a i$ & $p r$ & & $-a i$ & iCh'oa & $-e$ \\
\hline 2S.GEN & give. & & -PRF.P & hind.leg & -RTM \\
\hline nat & prabal'on & $g^{\prime} U a k$ & & & \\
\hline nat & prabal'on & $g^{\prime} U a k$ & $-a$ & & \\
\hline dance & Praba & child & & & \\
\hline
\end{tabular}

$\begin{array}{llllll}\text { s'aTuk } & \text { zhe } & \text { kuS'urek } & \text { ciSTuni'aka } & \text { zhus } & \\ \text { s'aTuk } & \text { zhe } & \text { kuS'urek } & \text { ciSTuni'aka } & \text { zhu } & \text {-s } \\ \text { apple-mash and bread } & \text { standing? } & \text { eat } & \text {-P/F.2S } \\ \text { you cannot sit down to eat your bread and apple-mash } & \end{array}$

\begin{tabular}{|c|c|c|c|c|c|}
\hline $\begin{array}{l}\text { gh'ora } \\
\text { gh'ora } \\
\text { white }\end{array}$ & $\begin{array}{l}\text { r'eZHai } \\
\text { reZH } \\
\text { trail }\end{array}$ & $\begin{array}{l}-\boldsymbol{a} i \\
-\mathrm{L} O \mathrm{C}\end{array}$ & $\begin{array}{l}\text { bas } \\
\text { bas } \\
\text { spend night }\end{array}$ & $\begin{array}{l}\text { prabal'on } \\
\text { prabal'on } \\
\text { Praba }\end{array}$ & $\begin{array}{l}\text { g'Uakan } \\
\text { g'Uak } \\
\text { child }\end{array}$ \\
\hline
\end{tabular}

you spend the night on the white trail, O Praba boys

$\begin{array}{llllll}\text { s'aTuk } & \text { zhe } & \text { kuS'urek } & \text { ciSTuni'aka } & \text { zhus } & \\ \text { s'aTuk } & \text { zhe } & \text { kuS'urek } & \text { ciSTuni'aka } & \text { zhu } & \text {-s } \\ \text { apple-mash } & \text { and } & \text { bread } & \text { standing? } & \text { eat } & \text {-P/F.2S } \\ \text { you cannot sit down to eat your bread and apple-mash } & \end{array}$




$\begin{array}{llllll}\text { t'ai } & \text { cAh'aka } & \text { Dh'ou } & \text { prabal'on } & \text { g'Uakan } \\ \text { t'ai } & \text { cAh'aka } & \text { Dh'ou } & \text { prabal'on } & \text { g'Uak } & \text {-an } \\ \text { 2S.GEN } & \text { thick.bread } & \text { heaping } & \text { Praba } & \text { child } & \text {-P.DIR } \\ \text { your thick bread cake, O Praba boys } & & & \end{array}$

\begin{tabular}{llllll} 
s'aTuk & zhe & kuS'urek & ciSTuni'aka & zhus & \\
s'aTuk & zhe & kuS'urek & ciSTuni'aka & zhu & -s \\
apple-mash and & bread & standing? & eat & -P/F.2S \\
\multicolumn{2}{l}{ you cannot sit down to eat your bread and apple-mash } &
\end{tabular}

\begin{tabular}{|c|c|c|c|c|c|}
\hline ek & ta & birb'o & eko & & juwar'i \\
\hline ek & ta & birb'o & $e k$ & -0 & juwar'i \\
\hline one & CORR & walnut & one & -CORR & corn \\
\hline$g E \sim ' a k$ & pra & 'on & 'Uakan & & \\
\hline $\boldsymbol{g} \boldsymbol{E} \sim \operatorname{ak}$ & pra & 'on & $\begin{array}{l}\text { 'Uak } \\
\text { Uald }\end{array}$ & $\begin{array}{l}-a n \\
-P D I R\end{array}$ & \\
\hline
\end{tabular}

a walnut and a corn-cob, Praba boys

\begin{tabular}{llllll} 
sanab'aci & kay & zhu & gazhag'azhi & kay & zhu \\
sanab'a ci & kay & zhu & gazhag'azhi & kay & zhu \\
corn.mash & do.CP & eat & walnut.butter & do.CP & eat:IMPV.2S \\
you eat bean \\
\hline
\end{tabular}

The prabal'on g'Uak, the boys of the god Praba, form as a group already on the day of goST-s'araz, the third day of Chaumos - when, as we have seen, they animate the torchlight procession with their crude insults against adults - and they conduct an extorsive ritual begging the following day to collect the grains to make bread during their seclusion. The verses of the song, as mentioned, celebrate their main ritual activities. The fox hunt of the first verse takes place on the day of koT SaT'ek: the prabal'on g'Uak, always keeping to the 'onjiSTa area of the goat-sheds, made the round of a mound overlooking the dancing ground yelling and raising a great commotion to chase away an invisible fox. The meaning of the ritual is somewhat obscure. Since the fox is an animal connected to the sexual sphere, ${ }^{12}$ it is probably taken as the symbol of the impurity that must be evicted from the 'onjiSTa area. The dance of the grazing goats of the second verse is a dance that the novices perform that same day in front of the

12 See the text in Cacopardo, A. S. 2008: 92 and Loude \& Lièvre 1984: 272. 
whole male community, imitating the movements of the goats when they rise on their hind legs to graze from the lower branches of the holly-oak trees. The 'white trail' of the third verse is the trail the prabal'on g'Uak follow during the second night of their seclusion to reach the shrine of Praba where the most sacred sacrifice of the year a holocaust - is celebrated at the break of dawn. It is called the 'white trail' because the boys reach the altar just when the white light of dawn begins to shine on the valley. The thick bread cake of the following verse is an offering they bring to the altar, which is called indr h'arik, to be brought to Indra. Also behind the god Praba, as we have seen is the case with Warin, looms indeed the figure of Indra; his name can be derived from pravabhra, a name of Indra found in the Maitrayani Samhita (T-8782). The refrain seems to refer to the hardships the prabal'on g'Uak have to go through. Informants were not sure of its exact meaning. They suggested that the boys could not sit down to eat because the goat-sheds sheltering them were too crowded or because the ground near the altar was covered with snow. The last two verses mention the food the boys eat during the seclusion, which apparently has to be mashed. Could that symbolize a baby-like status after the rebirth brought about by the initiation? It may be, though none of my assistants gave this explanation.

\section{Text no. 6}

After the prabal'on g'Uak have reached the shrine of Praba following the 'white trail', and the holocaust has been performed at the first lights, in the following morning the whole community slowly gathers on the main dancing ground, located more or less at the centre of the valley, not far from Praba's altar. Now all activities are carried out in broad daylight. It is the sixth day of Chaumos, one of the holiest, called koT SaT'ek, from its main ritual event. This is a race between runners of the two moieties that ends with the lighting up by the winner of a stack of brushwood piled up at Praba's shrine (Cacopardo, A. S. 2008: 94-95); but, as the text above relates, many other ritual activities are performed. While the men are busy with these, the women sing on the main dancing ground, just nearby. They are not allowed to watch the race nor any of the other rituals, because they 
take place in 'onjiSTa territory. The following song - like the preceding one - was recorded that day on the gri dancing ground.

\begin{tabular}{llllll} 
pilinsh'oa & & jeST'alas & & pilinsh'oa & \\
pilinsh'o & -a & jeST'ali & -as & pilinsh'o & -a \\
Pilinsho & GEN & m.law & -POSS.3.S & Pilinsho & GEN \\
jeST'alas & & & & \\
jeST'ali & -as & & & \\
m.law & -POSS.3.S & & \\
Pilinsho's & mother-in-law, Pilinsho's mother-in-law & \\
\hline
\end{tabular}

\begin{tabular}{|c|c|c|c|c|c|c|}
\hline 'indras & & k'oTuna & & par' & & kakaw'a k \\
\hline indr & $-a s$ & koT & -una & par & $-a$ & kakaw'a k \\
\hline $\begin{array}{l}\text { Indra } \\
\text { m'ari }\end{array}$ & -GEN & $\begin{array}{l}\text { tower } \\
\text { m'ai }\end{array}$ & $\begin{array}{r}-\mathrm{LOC} \\
\text { des }\end{array}$ & go & -PST.A.2S & chicken \\
\hline mar & $-i$ & m'ai & $d$ & & -es & \\
\hline kill & $-\mathrm{CP}$ & 1S.DAT & give & & -P/F.2S & \\
\hline
\end{tabular}

went to Indra's castle, you kill a chicken and offer it to me

\begin{tabular}{|c|c|c|c|c|}
\hline 'ala & $k^{\prime} y a$ & k'arim & & day \\
\hline 'ala & $k^{\prime} y a$ & kar & -im & d'ay \\
\hline DIST.S.ACC & what & do & -P/F.1S & P/F.CONT \\
\hline c'uri meS & m'ari & & m'ai & de \\
\hline c'uri meS & mar & $-i$ & m'ai & $d e$ \\
\hline braid ram & kill - & $-\mathrm{CP}$ & 1S.OBL & give.IMPV.2S \\
\hline
\end{tabular}

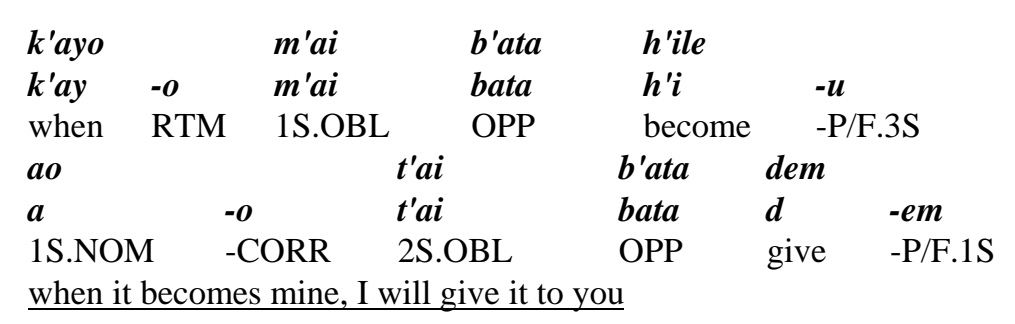

Like text no. 5, this is a Chaumos song and a women's song, as indicated also by the mention of the 'braid-ram' which is the animal offered for the initiation of a girl when, as she dons the female headdress, her hair is braided for the first time. According to Jettmar (1975: 356) indr'as koT is the place where a fire is lit at the indr'eyn 
shrine in Bumburet, to welcome the visiting god Balimain. ${ }^{13}$ In fact, it is more likely that the expression refers to the pile of wood which is lit, rather than to the place where it is lit. In Birir 'indras koT could be considered the two piles of brushwood held each by four poles, representing the two moieties, which stand by Praba's altar on the day of the race, ready to be lit by the runners. The song, like other Chaumos songs, is sung also in Bumburet and Rumbur. ${ }^{14}$ It is a jokingly ironic chant, sung at a lively rhythm, teasing those who give the worst of what they have: chicken are impure for the Kalasha and their meat is forbidden, while the meat of the 'braid-ram', the initiation ram, for a woman is the purest of all. The last verse, however, is of capital importance because it states most explicitly the principle of reciprocity on which Kalasha society is ideologically based, with an expression that reminds closely the Maori proverb reported by Mauss at the end of his famous Essai sur le don (Mauss 1965: 277). ${ }^{15}$

Text no. 7

In the songs sung by the women at Chaumos we may distinguish two genres. Some, like the preceding ones, celebrate the event. Others, which are called $L a c$ ghO (shameful songs), have a crude sexual content and make use of a language considered shameful in ordinary female speech. The text presented here is an example of this second genre. It was recorded on the gri dancing ground the evening of December $19^{\text {th }}$, the day of $k o T$ SaT'ek.

$\begin{array}{lllll}\text { shenm'aluk } & \text { b'itsaay } & & \text { g'ehenraw } & \\ \text { shenm'aluk } & \text { b'itsa } & -a y & \text { geh'en } & \text { r'aw } \\ \text { bed.end } & \text { gap } & \text {-LOC } & \text { side } & \text { as }\end{array}$

13 As I have shown in my former article on Chaumos (Cacopardo, A. S. 2008: 102-103), Balimain is also to be identified with Indra.

14 The virilocal marriage rule has probably always favoured the circulation of women's song in the three communities.

15 Which he translated as "donne autant que tu prends, et tout sera bien” (Mauss Ib.). 


$\begin{array}{lllll}\text { bhut } & \boldsymbol{a S} & \text { th'ara } & \boldsymbol{j}^{\prime} \boldsymbol{a i} & \\ \text { bhut } & \boldsymbol{a S} & \text { thar } & \mathbf{j} & -\boldsymbol{a i} \\ \text { trousers } & \text { shoulder } & \text { on } & \text { put } & -\mathrm{CP}\end{array}$

falling sideways in the gap at the end of the bed with his trousers thrown across his shoulder

\begin{tabular}{|c|c|c|c|c|c|c|c|}
\hline $\begin{array}{l}\text { s'enjilai } \\
\text { send } \\
\text { side }\end{array}$ & $\begin{array}{l}\boldsymbol{j} \\
\text { put }\end{array}$ & $\begin{array}{l}\text {-ila } \\
\text {-PERF.P }\end{array}$ & $\begin{array}{l}-i \\
- \text { RTM }\end{array}$ & $\begin{array}{l}\text { bh'utas } \\
\text { bhut } \\
\text { trousers }\end{array}$ & $\begin{array}{l}-a s \\
\text {-OBL }\end{array}$ & $\begin{array}{l}\boldsymbol{k}^{\prime} a y \\
\boldsymbol{k}^{\prime} \boldsymbol{a} y \\
\text { by }\end{array}$ & $\begin{array}{l}\text { she } \sim h^{\prime} e^{\sim} \\
\text { she } \sim h^{\prime} e^{\sim} \\
\text { thus }\end{array}$ \\
\hline m'atrila & & & se & & ne & & \\
\hline & -ila & & se & & ne & a & \\
\hline say & -PS & Г.HRS & REM.S.N & $\mathrm{M}$ & NEG & & HRS \\
\hline
\end{tabular}

having put his trousers by the side, ${ }^{16}$ he told her:

\begin{tabular}{|c|c|c|c|}
\hline tu & mi & se & $m^{\prime} a i$ \\
\hline & $-m i$ & se & $m^{\prime} a i$ \\
\hline 2S.NOM & -INT & REM.S.NOM & 1S.GEN \\
\hline
\end{tabular}

you yourself will be my wife's sister

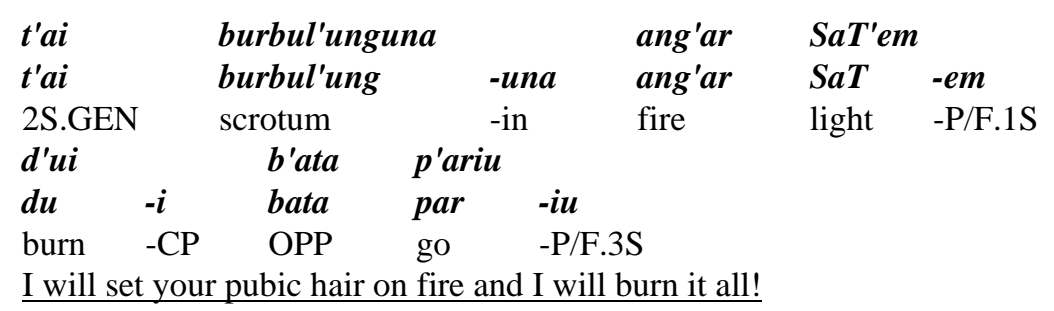

\begin{tabular}{|c|c|c|c|c|c|}
\hline jeST'ali & \multicolumn{2}{|c|}{ gho } & \multicolumn{3}{|c|}{ taL'ey } \\
\hline jeST'ali & & $0^{\sim}$ & & & $-e y$ \\
\hline w.mother & & & & $\mathrm{M}$ & -OBL \\
\hline prej'ey & gher' & & las'ai & & \\
\hline prej'ey & gher & $-a i$ & las & $-a$ & \\
\hline w.sister & turn & $-\mathrm{CP}$ & leave & $-\mathrm{I}$ & P.2S \\
\hline
\end{tabular}

said the mother of the wife, and forget all about this wife's sister business!

16 I am quite sure this is the meaning of the sentence, though its structure remains a bit enigmatic. My assistant found it difficult to translate. 


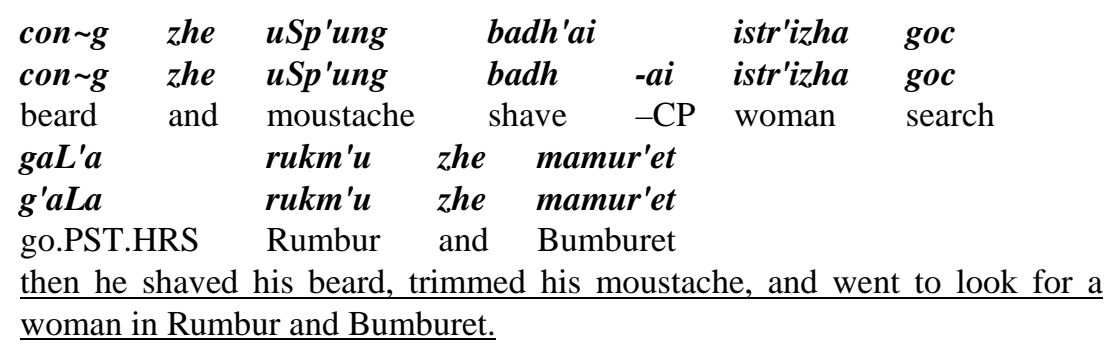

The song makes fun of a man who is trying to make a pass at his mother-in-law demanding she make up for the refusal of her daughter; but since sexual relations of this type are considered incestuous, the man tells her that she will be for him like a sister-in-law, with whom sexual relations, though deemed illegitimate, are not tabooed. The woman rejects him and pushes him to the end of the bed where the ropes holding the mattress are further apart, to the point that the pursuer falls through them with one of his legs and remains there half naked with his trousers thrown across his shoulders. The woman, further, threatens to set on fire the hair of his scrotum and makes clear that he better forget about that exchange. The threat is apparently effective, because the man trims his moustache and beard and goes to look for a woman in the other two valleys. The scene is less improbable than it may appear to a western eye, because, since Kalasha girls are often already married in their very early teens to men quite a bit older, a mother-in-law may be still a young woman, possibly even not older than her son-in-law.

Text no. 8

The text below is another example of $L a c g h O \sim$ recorded on the same day and from the same group of women as the preceding one.

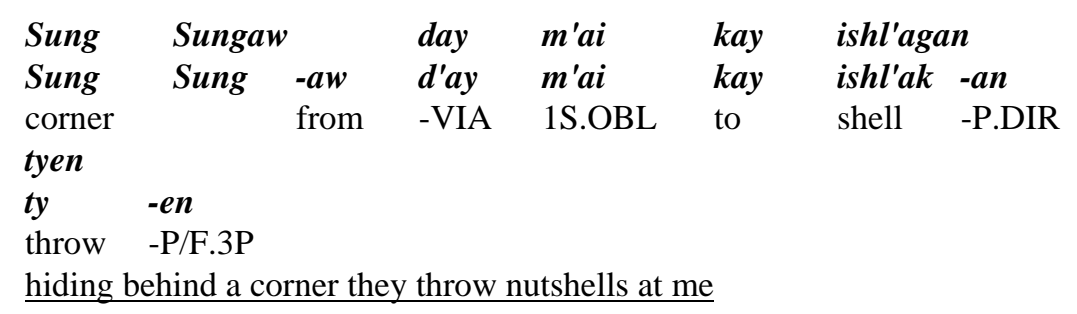




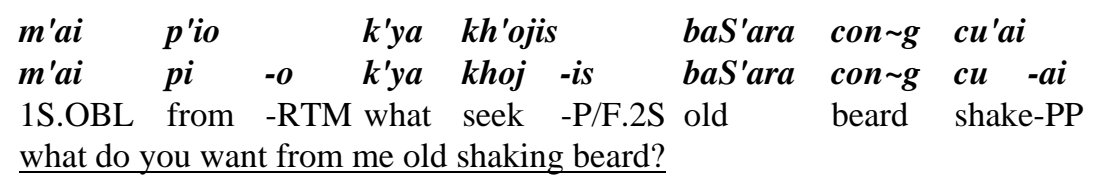

\begin{tabular}{|c|c|c|c|c|c|c|c|}
\hline $\begin{array}{l}\text { eil'a } \\
\text { eil'a }\end{array}$ & $\begin{array}{l}\text { ol'a } \\
\text { ol'a }\end{array}$ & $\begin{array}{l}\text { t'aisom } \\
\text { t'ai }\end{array}$ & -som & $\begin{array}{l}\text { c'ilu } \\
\text { c'ilu }\end{array}$ & $\begin{array}{l}\text { m'alu } \\
\text { m'alu }\end{array}$ & $\begin{array}{l}\text { sh'iaw } \\
\text { shi }\end{array}$ & $-a w$ \\
\hline RTM & RTM & 2S.OBL & -with & hookah & ECO & be.INAN & PST.A.3S \\
\hline
\end{tabular}

you have a hookah and all the rest

\begin{tabular}{llll} 
te & tambak'u & \multicolumn{2}{l}{ khaS'an } \\
te & tambak'u & khaS & -an \\
REM.P.NOM & tobacco & apply & -PST.A.3P \\
\hline
\end{tabular}

they put tobacco into it

$\begin{array}{lllll}\text { 'ia } & \text { sh'arum } & \text { tr'eyla } & \text { gh'o } \boldsymbol{n} & \\ \text { 'ia } & \text { sh'arum } & \text { tr'eyla } & \text { gho } & -\boldsymbol{n} \\ \text { PROX.S.NOM } & \text { sexual.organ } & \text { coarse } & \text { say } & -\mathrm{P} / \mathrm{F} .3 \mathrm{P} \\ \text { this sexual organ is coarse, they say } & & & \end{array}$

\begin{tabular}{|c|c|c|c|c|c|}
\hline $\begin{array}{l}\text { istrizh'on } \\
\text { istr'izha }\end{array}$ & -on & $\begin{array}{l}\text { som } \\
\text { som }\end{array}$ & $\begin{array}{l}\text { mo } \\
\text { mo }\end{array}$ & $\begin{array}{l}\text { pras'ua } \\
\text { prasu }\end{array}$ & $-a$ \\
\hline $\begin{array}{l}\text { woman } \\
\text { do not sleep }\end{array}$ & $\begin{array}{l}-\mathrm{P} . \mathrm{OBL} \\
\text { th womes }\end{array}$ & -with & NEG & sleep & -IMP.2P \\
\hline
\end{tabular}

$\begin{array}{lllll}\boldsymbol{t} \text { 'ai } & \text { aC'una } & \boldsymbol{w A} & \text { tri'iu } & \\ \boldsymbol{t} \text { 'ai } & \text { 'aCuna } & \boldsymbol{w A} & \text { tri } & - \text { iu } \\ \text { 2S.GEN } & \text { dried.up } & \text { scrotum } & \text { split } & \text {-P/F.3S }\end{array}$

your shrivelled scrotum will split

We have here another ironic scene in which a woman teases poignantly an older man who tries to flirt with her in a childish way, throwing nutshells at her from behind a corner. The pipe and the tobacco are probably sexual allusions. The sexual organs, at any rate, are explicitly named in the subsequent verses in which the girl accuses the man of having an exceedingly coarse organ and urges him to forget about women because his shrivelled scrotum would split. As in the preceding song, the woman rejects the man who is ridiculed in his virility. 
In both texts the male-female opposition comes to the fore. This is one of the central themes of Chaumos. While the prabal'on g'Uak are in seclusion in the area of the goat-sheds, the women appear to take the lead in the ritual activities carried out in the villages. It seems to be their task, especially, to stimulate the energy of reproduction with the shameful songs. ${ }^{17}$ The obscene is one of the key dimensions of Chaumos in Rumbur and Bumburet (cf. Loude \& Lièvre 1984: 214, 272, 282-285, 287, 289, 293-294; Snoy 2008: 50; Wutt 1983) where often improvised 'shameful songs' are sung in unison in true chanting contests between opposing parties of men and women, mainly instigated by the latter. In Birir these songs were sung only by women in unison, with no rival dancing party of men, and the verses were not improvised: they were old songs, I was told. ${ }^{18}$ Chanting contests with the two parties addressing each other as mai b'aya ko, "my dear brother" or mai baba ko, "my dear sister" - did take place that same day especially on the way to the dancing ground, but their verses were more of a romantic than a crudely sexual nature. In the Chaumos of Birir, the obscene in general seems in fact to have a less prominent role than it has in the festivals of the two northern valleys. Maybe because it is the central theme of another celebration - the Prun festival which does not exist in the other two valleys - or, more likely, because of the higher number of converts in Birir, and of the absence of the period of $d i C$ - a sort of 'village cloistering' - when, in Bumburet and Rumbur, the Muslims are physically banned from Kalasha villages.

\section{Text no. 9}

This song belongs like the preceding ones to the repertoire of women, but here the singer is a mother, not a pursued sexual partner like in the

17 For the relation between obscene words and behaviours and fertility of humans and nature in New Year celebrations see, e.g. Caillois 2001: 117; Eliade 1976: 372-73; Lanternari 1983: 517-519; Propp 1978: 209-211.

18 They were solicited, I am not sure to which extent, by one of my assistants who - not on my request - addressed a chanting group of women urging them to sing 'old' songs. 
shameful songs. Like the last four texts presented, the song was recorded on the gri dancing ground, from the same group of women.

\begin{tabular}{lllll} 
goST & d'uruna & \multicolumn{3}{c}{ par'a } \\
goST & dur & -una & par & -a \\
goat.shed & house & -in & go & -PST.A.2S \\
goST & d'uruna & & par'a & \\
goST & dur & -una & par & - $\boldsymbol{a}$ \\
goat.shed & house & -in & go & -PST.A.2S \\
\multicolumn{4}{l}{ you went to the goat-shed, you went to the goat-shed } \\
\hline
\end{tabular}

\begin{tabular}{|c|c|c|c|c|c|}
\hline $\begin{array}{l}\text { khe } \\
\text { khe } \\
\text { how }\end{array}$ & $\begin{array}{l}\text { h'iu } \\
\text { hi } \\
\text { become }\end{array}$ & $\begin{array}{l}-\boldsymbol{u} \\
-\mathrm{P} / \mathrm{F} .3 \mathrm{~S}\end{array}$ & $\begin{array}{l}\text { se } \\
\text { se } \\
\text { REM.S.NOM }\end{array}$ & $\begin{array}{l}\boldsymbol{m} \text { 'ai } \\
\text { m'ai } \\
1 \text { 1S.GEN }\end{array}$ & $\begin{array}{l}\text { butr'uk } \\
\text { butr'uk } \\
\text { child }\end{array}$ \\
\hline
\end{tabular}

how is he doing, my baby?

\begin{tabular}{|c|c|c|c|c|c|}
\hline $\begin{array}{l}\boldsymbol{n} \boldsymbol{e} \\
\boldsymbol{n} \boldsymbol{e} \\
\text { RTM }\end{array}$ & $\begin{array}{l}\text { khe } \\
\text { khe } \\
\text { how }\end{array}$ & $\begin{array}{l}\text { h'iu } \\
\text { hi } \\
\text { become }\end{array}$ & $\begin{array}{l}\text {-u } \\
\text { P/F.3S }\end{array}$ & $\begin{array}{l}\text { m'ai } \\
\text { m'ai } \\
\text { 1S.GEN }\end{array}$ & $\begin{array}{l}\text { butr'uk } \\
\text { butr'uk } \\
\text { child }\end{array}$ \\
\hline
\end{tabular}

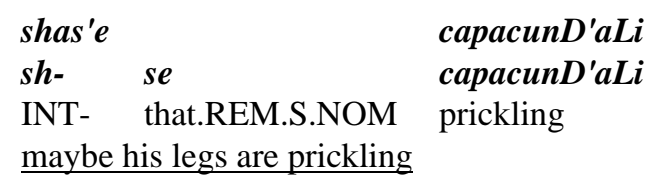

It is the song of a mother who worries for the hardships her 'baby' will encounter as a novice, during the seclusion in the area of the goatsheds. "Is he doing fine? Will he be uncomfortable? Will he get cramps?" asks the preoccupied mother. The text shows that for the novices the days of seclusion are an initiatory trial. A trial consisting in the almost sleepless nights in the crowded goat-sheds, in the sudden risings, in the arduous mountain trail that the boys have to negotiate in the dark with the only light of their pine torches. Not a trial requiring 
the endurance of strong physical pain, as is the case in other contexts, but still a trial for children aged no more than ten.

Text no. 10

This song is sung on the seventh and last day of Chaumos, the feast of the beans $\left(d A^{\prime} u\right.$ tat' $\left.u\right)$, by groups of young girls who, separately in each village, make the round of all the houses begging for beans. Since the ritual begging took place in the afternoon when the dances were still going on in the temple of Aspar village, I only caught a glimpse of the last part of the ceremony and could not record their singing. The words of their song were dictated to me the next day by the wife of my host.

$\begin{array}{lllllll}\boldsymbol{d} \boldsymbol{A}^{\prime} \mathbf{u} & \boldsymbol{b i} & \boldsymbol{g r i} & \text { tru'aio } & & & \\ \boldsymbol{d} \boldsymbol{A}^{\prime} \boldsymbol{u} & \boldsymbol{b i} & \boldsymbol{g r i} & \boldsymbol{t r u} & -' \boldsymbol{a} & -\mathbf{i} & -\boldsymbol{o} \\ \text { beans } & \text { seed } & \text { with } & \text { grow } & \text {-CAUS } & \text {-IMPV.2S } & \text {-RTM } \\ \text { make beans and their seed grow } & & & \end{array}$

\begin{tabular}{|c|c|c|c|c|c|}
\hline sharal'a & & tru'aio & & & \\
\hline sh'ara & $-l a$ & tru & -'a & $-i$ & -0 \\
\hline $\begin{array}{l}\text { markhor } \\
\text { make the }\end{array}$ & $\begin{array}{l}\text {-ENDM } \\
\text { markhor i }\end{array}$ & $\begin{array}{l}\text { grow } \\
\text { crease }\end{array}$ & -CAUS & -IMPV.2S & -RTM \\
\hline
\end{tabular}

\begin{tabular}{|c|c|c|c|c|c|c|}
\hline rashm'uk & $b i$ & gri & tru'aio & & & \\
\hline rashm'uk & bi & gri & & $-' a$ & $-i$ & -0 \\
\hline speckled.bean & seed & with & grow & -CAUS & -IMPV.2S & -RTM \\
\hline
\end{tabular}

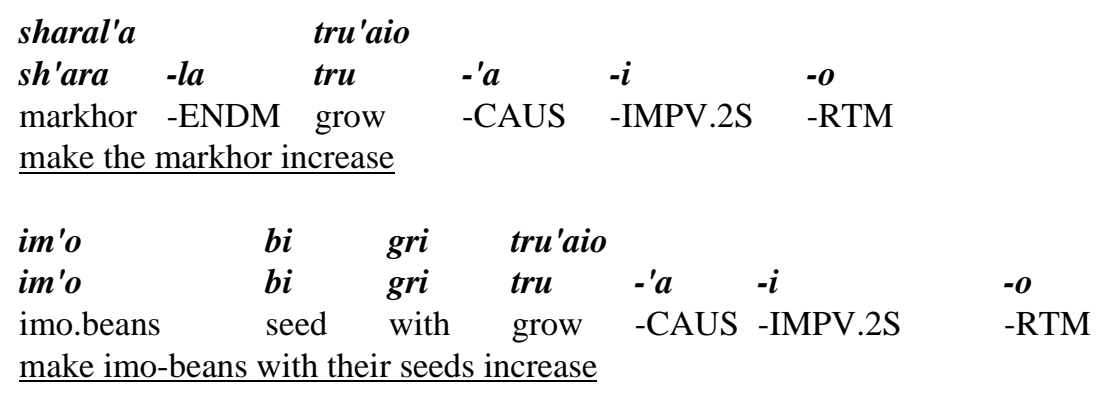




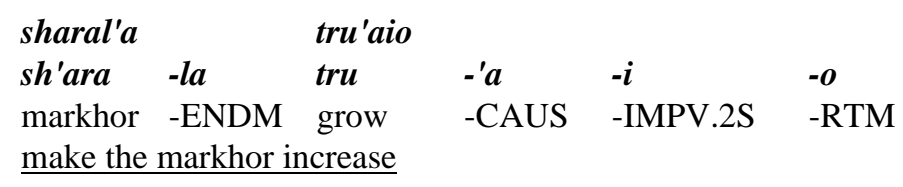

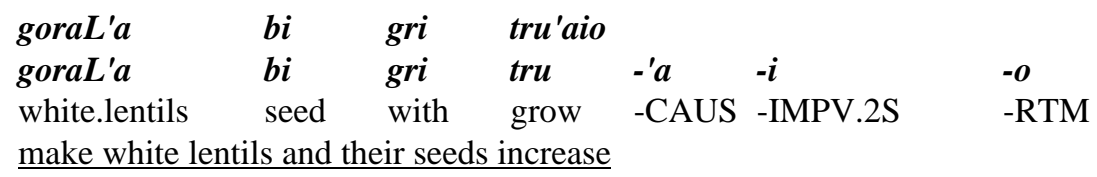

\begin{tabular}{llllll} 
sharal'a & \multicolumn{1}{c}{ tru'aio } & & \\
sh'ara & -la & tru & $-' a$ & $-\mathbf{i}$ & $-\boldsymbol{o}$ \\
markhor & -ENDM & grow & -CAUS & -IMPV.2S & -RTM \\
make the markhor increase & & &
\end{tabular}

\begin{tabular}{|c|c|c|c|c|c|c|}
\hline$p^{\prime} a y$ & bi & gri & tru'aio & & & \\
\hline$p^{\prime} a y$ & bi & gri & tru & $-' a$ & $-i$ & -0 \\
\hline she.goat & seed & with & grow & -CAUS & -IMPV.2S & -RTM \\
\hline
\end{tabular}

\begin{tabular}{|c|c|c|c|c|}
\hline sharal'a & tru'aio & & & \\
\hline sh'ara -la & tru & $-' a$ & $-i$ & -0 \\
\hline markhor-ENDM & $\begin{array}{l}1 \text { grow } \\
\text { or increast }\end{array}$ & -CAUS & -IMPV.2S & -RTM \\
\hline
\end{tabular}

$\begin{array}{llllll}\text { baty'a bi } & \text { gri } & \text { tru'aio } & & \\ \text { baty'a bi } & \text { gri } & \text { tru } & \text {-'a } & -\boldsymbol{i} & -\boldsymbol{c} \\ \text { goat.kid seed } & \text { with } & \text { grow } & \text {-CAUS } & \text {-IMPV.2S } & \text {-RTM }\end{array}$

make goat-kids and their seed increase

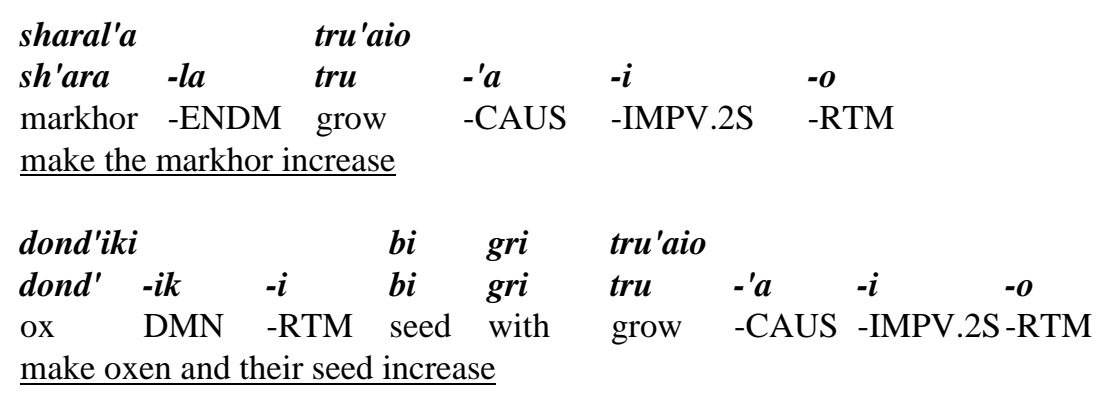




\begin{tabular}{|c|c|c|c|c|c|}
\hline $\begin{array}{l}\text { sharal'a } \\
\text { sh'ara }\end{array}$ & $-l a$ & $\begin{array}{l}\text { tru'aio } \\
\text { tru }\end{array}$ & -'a & $-i$ & $-O$ \\
\hline $\begin{array}{l}\text { markhor } \\
\text { make the }\end{array}$ & $\begin{array}{l}\text {-ENDM } \\
\text { markhor i }\end{array}$ & $\begin{array}{l}\text { grow } \\
\text { crease }\end{array}$ & -CAUS & -IMPV.2S & -RTM \\
\hline
\end{tabular}

\begin{tabular}{|c|c|c|c|c|c|c|c|}
\hline baCh'Oaka & & & $b i$ & gri & tru'aic & & \\
\hline baCh'Oa & $-k$ & $-a$ & bi & gri & tru & -'a & -0 \\
\hline & -DMN & -RTM & seed & with & grow & -CAUS & -IMPV.2S-RTM \\
\hline
\end{tabular}

\begin{tabular}{llllll} 
sharal'a & \multicolumn{1}{c}{ tru'aio } & & \\
sh'ara & - la & tru & $-' a$ & $-i$ & $-o$ \\
markhor & -ENDM & grow & -CAUS & -IMPV.2S & -RTM \\
make the markhor increase & & &
\end{tabular}

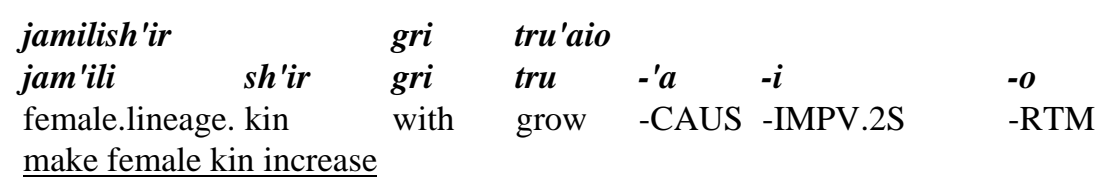

\begin{tabular}{llllll} 
sharal'a & \multicolumn{1}{c}{ tru'aio } & & \\
sh'ara & - la & tru & -'a & -i & -o \\
markhor & -ENDM & grow & -CAUS & -IMPV.2S & -RTM \\
make the markhor increase & & &
\end{tabular}

$\begin{array}{llllll}\text { graur'i } & \text { gri } & \text { tru'aio } & & \\ \text { graur'i } & \text { gri } & \text { tru } & \text {-'a } & -\mathbf{i} & - \text { o } \\ \text { men } & \text { with } & \text { grow } & \text {-CAUS } & \text {-IMPV.2S } & \text {-RTM }\end{array}$

$\underline{\text { make male kin increase }}$

\begin{tabular}{llllll} 
sharal'a & \multicolumn{1}{c}{ tru'aio } & & \\
sh'ara & -la & tru & -'a & $-\mathbf{i}$ & -o \\
markhor & -ENDM & grow & -CAUS & -IMPV.2S & -RTM \\
make the markhor increase & & &
\end{tabular}

$\begin{array}{lllllll}\text { moc } & \text { kuw'at } & \text { gri } & \text { tru'aio } & & \\ \text { moc } & \text { kuw'at } & \text { gri } & \text { tru } & \text {-'a } & -\boldsymbol{i} & -\mathbf{o} \\ \text { men } & \text { strength } & \text { with } & \text { grow } & \text {-CAUS } & \text {-IMPV.2S } & \text {-RTM } \\ \text { make virile strength increase } & & & \end{array}$




\begin{tabular}{|c|c|c|c|c|c|}
\hline sharal'a & & tru'aio & & & \\
\hline sh'ara & $-l a$ & tru & -'a & $-\mathbf{i}$ & -0 \\
\hline $\begin{array}{l}\text { markhor } \\
\text { make the }\end{array}$ & $\begin{array}{l}\text {-ENDM } \\
\text { markhor } \mathrm{i}\end{array}$ & $\begin{array}{l}\text { grow } \\
\text { crease }\end{array}$ & -CAUS & -IMPV.2S & -RTM \\
\hline
\end{tabular}

Reproduction and fertility are the manifest themes of the chant. The last verse invokes abundance of male energy, without which there can be no generation, while the other verses invoke abundance of everything: of the fruits of the earth, of animals, of offspring. They ask especially for abundance of all types of beans and lentils for the fact, we can surmise, that pulses are the main food in the winter. ${ }^{19}$ The refrain, that invokes the multiplication of the markhor (capra falconeri), seems to testify to the past importance of the meat of these wild goats in the diet of the Kalasha, ${ }^{20}$ as well as to their significance as symbols of abundance (cf. Lièvre \& Loude 1990: 48). In winter, as they migrate to lower altitudes they become an easier prey for hunters.

The text does not mention the name of any god, but the fact that in all verses the verb is in the second person of the imperative indicates that the chant must be implicitly addressed to some divinity. The most appropriate addressee of such requests would no doubt be Jeshtak (j'eSTak), the goddess presiding over family relations and reproduction, who is invoked with very similar verses in the $d A^{\prime} u$ tat'u of Rumbur (Loude \& Lièvre 1984: 302-310). The song is repeated by the girls on the doorsteps of each house and it has essentially a wellwishing function: to each family they wish abundance of everything. It is significant, we may note, that the prayer for fertility is chanted by young girls who are the most apt to impersonate the idea of a budding seed.

\section{Text no. 11}

This song I recorded from the voices of a group of little girls who were playfully singing and dancing in the temple on the night of $d A^{\prime} u$ tat'u. The pulses collected in the afternoon had been brought there for

19 Pulses, on the other hand - for the fact that they are seeds and as such contain the potential of life - may be seen as symbols of abundance (Propp 1978: 47).

20 Women are allowed to eat some parts of these wild animals (Lièvre \& Loude 1990: 72) 
a communal cooking and were boiling in two large aluminium pots set on two lively fires lit under the wooden porch of the building. The party seemed to be only for youngsters and adults would only occasionally peep in. The beans cooked all night and were distributed to all the families in the village the following morning.

\begin{tabular}{|c|c|c|c|c|c|c|}
\hline cid'inik & & t'ai & buny'ate & & gak & Sing'Oyak \\
\hline cid'in & $-i k$ & $t^{\prime} a i$ & buny'at & $-e$ & gak & Sing'Oyak \\
\hline iron.pot & -DMN & 2S.GEN & bribe & -RTM & cow & hornlet \\
\hline
\end{tabular}

\begin{tabular}{|c|c|c|c|c|c|c|c|}
\hline $\begin{array}{l}\text { m'ai } \\
\text { m'ai }\end{array}$ & $\begin{array}{l}\text { chu } \\
\text { ch'ul }\end{array}$ & $\begin{array}{l}\text { t'ai } \\
\text { t'ai }\end{array}$ & $\begin{array}{l}j a \\
\text { ja }\end{array}$ & $\begin{array}{l}\text { ne } \\
\text { ne }\end{array}$ & $\begin{array}{l}\text { d'eme } \\
\text { d }\end{array}$ & -em & $\begin{array}{l}-\boldsymbol{e} \\
-\mathrm{RTM}\end{array}$ \\
\hline & $\begin{array}{r}\text { daughter } \\
\text { Sing'Oyak }\end{array}$ & 2S.OBL & wife & NEG & give & -P/F.1S & -RTM \\
\hline gak & Sing'Oyak & & & & & & \\
\hline $\begin{array}{l}\text { cow } \\
\text { but I sha }\end{array}$ & $\begin{array}{l}\text { hornlet } \\
\text { ll not give y }\end{array}$ & & & & & & \\
\hline
\end{tabular}

\begin{tabular}{|c|c|c|c|c|c|c|}
\hline i'donik & & $t^{\prime} a i$ & buny'ate & & gak & $\begin{array}{l}\text { Sing'Oyak } \\
\text { Sing'Oyak }\end{array}$ \\
\hline $\begin{array}{l}\text { i'don } \\
\text { tripod }\end{array}$ & $\begin{array}{l}-\mathbf{i k} \\
-\mathrm{DMN}\end{array}$ & $\begin{array}{l}\boldsymbol{t}^{\prime} \boldsymbol{a i} \\
\text { 2S.GEN }\end{array}$ & $\begin{array}{l}\text { buny'at } \\
\text { bribe }\end{array}$ & $\begin{array}{l}-\boldsymbol{e} \\
-\mathrm{RTM}\end{array}$ & $\begin{array}{l}\text { gak } \\
\text { cow }\end{array}$ & $\begin{array}{l}\text { Sing'Oyak } \\
\text { hornlet }\end{array}$ \\
\hline
\end{tabular}

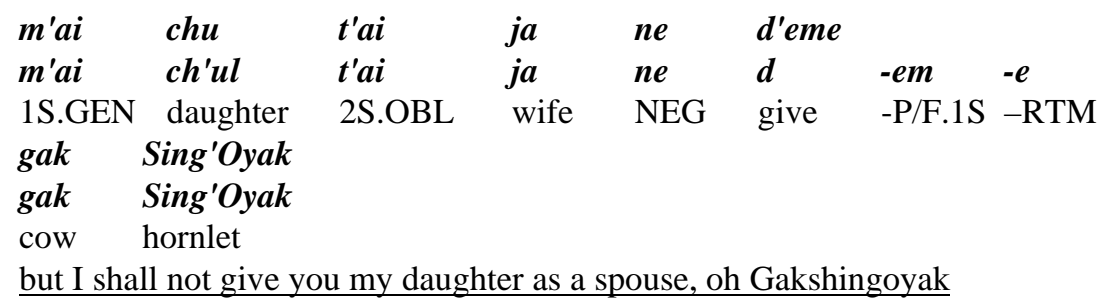

$\begin{array}{llllll}\text { aZH'aRik } & \text { t'ai } & \text { buny'ate } & \text { gak } & \text { Sing'Oyak } \\ \text { aZH'aRi -ik } & \text { t'ai } & \text { buny'at } & -\boldsymbol{e} & \text { gak } & \text { Sing'Oyak } \\ \text { apricot -DMN } & \text { 2S.GEN } & \text { bribe } & \text {-RTM } & \text { cow } & \text { hornlet }\end{array}$
you try to bribe me with apricots, oh Gakshingoyak

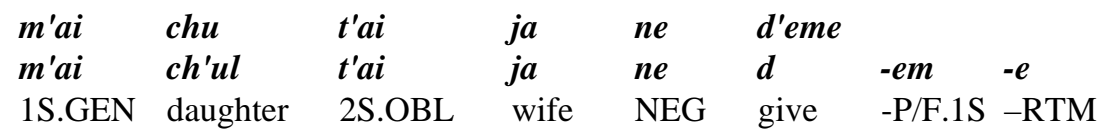


$\begin{array}{ll}\text { gak } & \text { Sing'Oyak } \\ \text { gak } & \text { Sing'Oyak } \\ \text { cow } & \text { hornlet } \\ \text { but I shall not give you my daughter as a spouse, oh Gakshingoyak }\end{array}$

The lyrics of the song are an apparent expression of female solidarity. The issue is that of a woman's role in the choice of her husband. Marriage among the Kalasha (Maggi 2001: 167-212) is traditionally organized by the father when the girl is still a child, in response to proposals coming from the family of the prospective groom. As text no.15 also testifies, Kalasha girls sometimes accuse their fathers of "having sold them" when they do not like the choice he made for them: ${ }^{21}$ the iron tripods and the vessels for cheese-making mentioned in the verses, are the objects traditionally composing the mal, the bride-price. In the song we hear the voice of a mother who is trying to protect her daughter. The name gakshing'oiak is probably a derogatory nick-name for an unwelcome aspirant; literally it means "little cow horn”, a clear phallic allusion. The woman addresses him saying that if he thinks he can bribe her with his gifts, he is mistaken. She will never let him marry her daughter. The song expresses thus the plight of Kalasha girls when they are given in marriage to men much older than they are, who take them away from their homes and friends when they are still in their childhood. ${ }^{22}$

\section{Text no.12}

This text was recorded between 4:00 and 5:00 a.m. of January $6^{\text {th }}$ 2007. It is a prayer (suw'al) - not a song ( $g h O \sim)$, I was told - that was chanted by a group of women, one for each household, gathered around a fire in the temple of Guru village. It is part of a ritual that

21 Kalasha tradition, however, offers an escape from situations of unbearable unhappiness: the woman may elope with a man of her choice if her new mate is ready to pay the double of the bride-price to the abandoned husband. The institution called $a L a S^{\prime} i n \sim g$ is discussed at length in Parkes 1983 and Maggi 2001.

22 According to several people I questioned, fathers no longer impose their choices on their daughters; but without behavioural data we cannot really draw any conclusions on the subject. 
takes place for Lagaur, a festival that follows Chaumos after a couple of weeks and is connected to it. It includes some ceremonies that in the two northern valleys are considered an integral part of Chaumos. Lagaur lasts altogether ten days but it is not as intense as the winter solstice feast: in the first two days the only ritual activity is a special meal consumed in the evenings, while the last $\operatorname{six}^{23}$ concern only children who dance and imitate the ritual activities of Chaumos. It has an explicit pedagogic character: "we teach them to play the drums," I was told, "so that they will not become Muslims." After participating in Chaumos mostly as spectators, children are given the opportunity to be the actors without any adult supervision. A practice of peereducation, it would seem.

The nocturnal chant in the temple is maybe the core event of the two central days of Lagaur. The day before, animal figurines of dough are made in the homes to ensure the reproduction of useful animals, while young girls sing to call the White Crow and fetch green branches to decorate the temples. The White Crow is a supernatural being, bringer of wealth and fertility, who visits the Kalasha at this time. The prayer recorded that night was addressed to him.

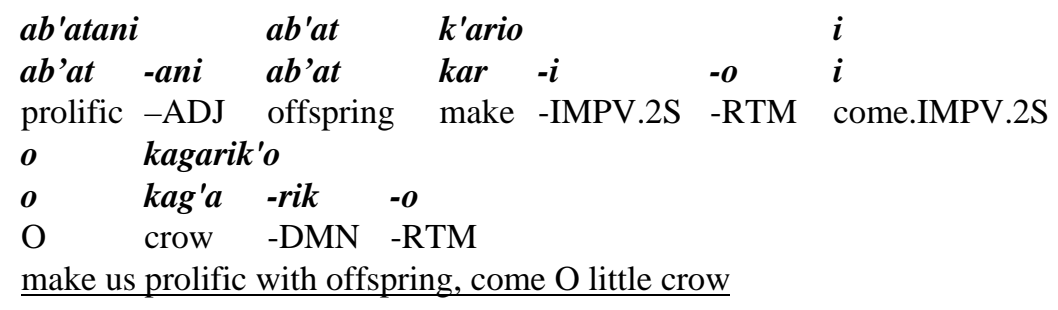

23 In 2007 these were reduced to only two because of a funeral celebration that had to be held just then. 


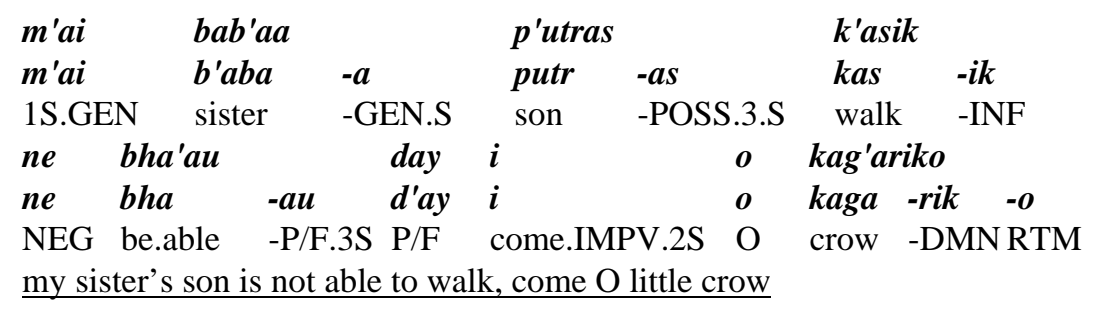

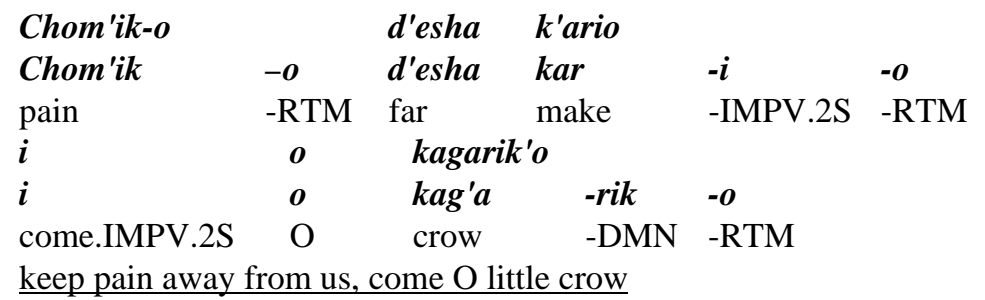

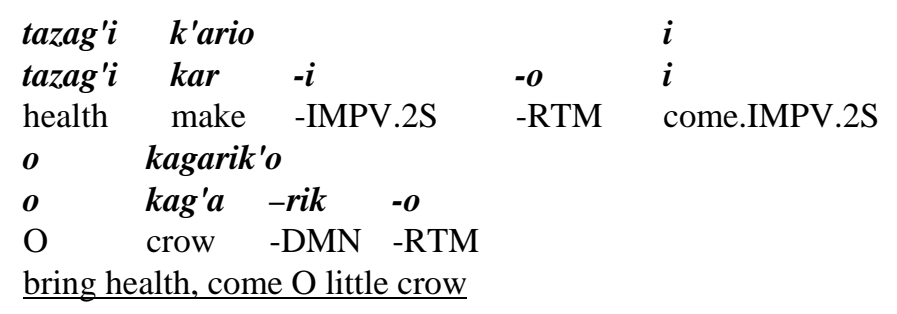




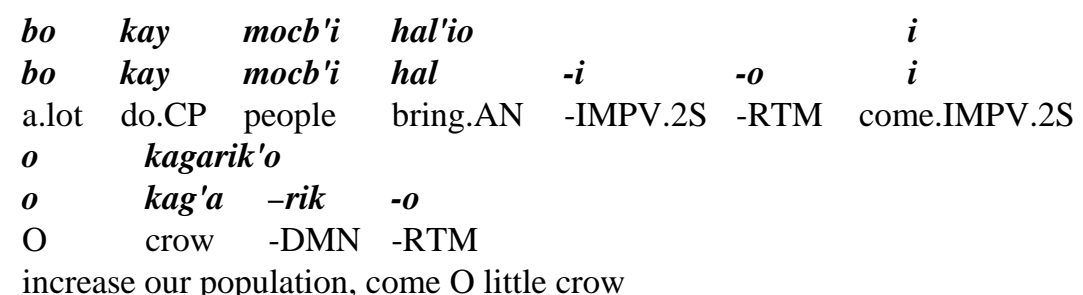

increase our population, come O little crow

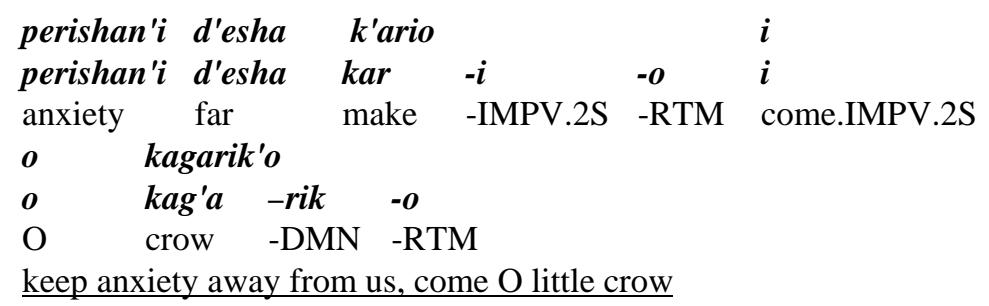

keep anxiety away from us, come O little crow

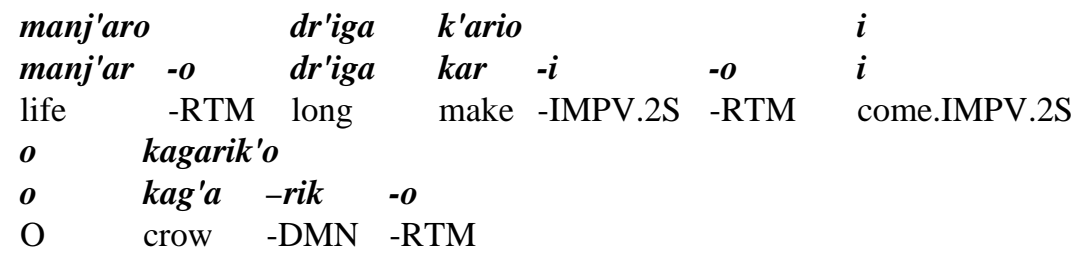




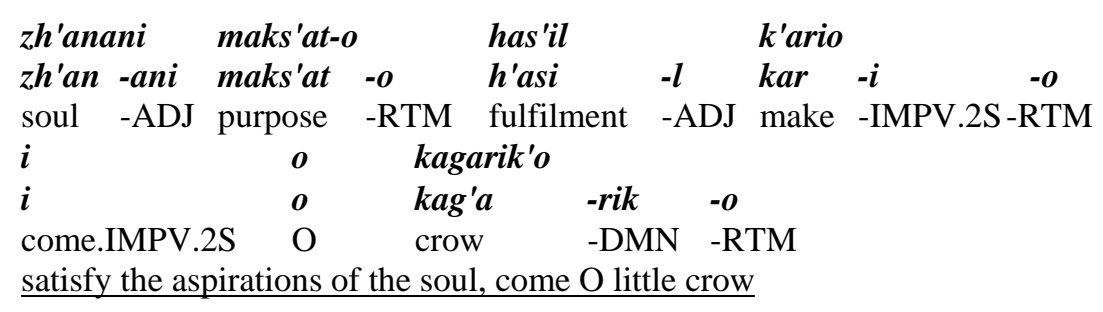

The chant had an imploring and melancholy tone. A soloist, in turns, would call out a verse, and the others repeated it in unison. The verses invoke happiness, well-being and a long life. They ask to avert anxiety and sorrow; but most of all they express the wish for fertility and reproduction. The text contains also two specific requests: one by a woman who prayed for her sister's son who could not walk; and one on my behalf, that I may be granted a male son soon. ${ }^{24}$ The White Crow is seen as a messenger, as an intermediary who carries the wishes of humans to God, called Allah, as in the Quran: the identification of the Supreme Being of the Kalasha pantheon with the God of Islam, as we have seen, is now an established fact. The prayer ends with a verse asking the Crow to fulfil all the aspirations of the soul. A conclusion in which we may discern a recurring theme of winter feasts: the descent of a benevolent being who fulfils all wishes.

\section{Text no.13}

The melancholy chanted prayer ended after less than an hour, and the following song, sung in a merry tune that created a sharp contrast, concluded the ritual for the White Crow.

$\begin{array}{lllll}\text { tr'iku } & \text { tr'aku } \quad \text { ie } & & \text { kag'arik } & \\ \text { tr'iku tr'aku } \quad \boldsymbol{i} & -\boldsymbol{e} & \text { kag'a } & \text {-rik } \\ \text { crow crow come.IMPV.2S } & -\mathrm{RTM} & \text { crow } & \text {-DMN } \\ \text { crow crow, come little crow } & & & \end{array}$




$\begin{array}{llllll}\text { w'iku } & \text { w'aku } & \text { ie } & & \text { kag'arik } & \\ \text { w'iku } & \text { w'aku } & \boldsymbol{i} & -\boldsymbol{e} & \text { kag'a } & \text {-rik } \\ \text { crow } & \text { crow come.IMPV.2S } & \text {-RTM } & \text { crow } & \text {-DMN }\end{array}$

crow crow, come little crow

\begin{tabular}{|c|c|c|c|c|c|}
\hline$t^{\prime} a i$ & ta & r'iCuna & & LO'an & \\
\hline$t^{\prime} a i$ & ta & riC & -una & $L O$ & $-a n$ \\
\hline $\begin{array}{l}2 S . O B L \\
\text { for you th }\end{array}$ & $\begin{array}{l}\text { CORR } \\
\text { ey prepare }\end{array}$ & $\begin{array}{l}\text { excrement } \\
\text { excrement }\end{array}$ & - in & $\operatorname{mix}$ & -P/F.3P \\
\hline mai'o & & m'onDuna & & LO'an & \\
\hline 'ai & -0 & monD & -una & $L O$ & $-a n$ \\
\hline 1S.OBL & -CORR & whey & - in & $\operatorname{mix}$ & -P/F.3P \\
\hline
\end{tabular}

for me they prepare whey

The song is addressed to the real crows this time, ironically reminding them that they eat excrement. After a short while the lively song was interrupted abruptly and the women streamed out of the temple, each with a piece of burning wood from the fire in one hand, and a small aluminium cup with offers of cracked walnuts in the other, which they emptied down the slope from the porch of the temple. The real crows are supposed to arrive at this time to consume the offerings, if the incoming year is to be a fortunate one. I set my gaze in the obscurity to see if I could spot a crow, but under the trees the veil of darkness was still too thick.

\section{Text no.14}

Once the prayer to the White Crow was over and the women were back in their homes, a man from each household was supposed to leave at dawn for the goat-sheds carrying as a gift a large bread-cake with a decoration representing a herd on its surface, baked in the homes the previous evening, along with a few dough figurines. I went with one of the men. The goat-shed we reached after an hour's walk in the snow was crowded with children and a few men. The large bread cake was split and distributed, while a few cups of wine made the round of all present, children included. Stimulated by the wine, one of the men sang the song transcribed below. Though I had not heard it yet in Birir, the song was not new to me. I had heard it at the Rumbur Chaumos in 1973 where it was chanted by the whole community on 
the holiest night of the festival (Cacopardo A.S. 1985: 746; Cacopardo \& Cacopardo 1989: 325; cf. Loude \& Lièvre 1984: 287; Snoy 2008: $62)$. The melody was now different, but the chant was no doubt the same one. Even if in no way solicited, it was seemingly not in its proper ritual context.

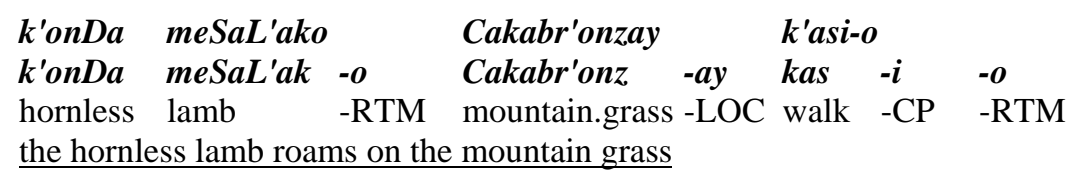

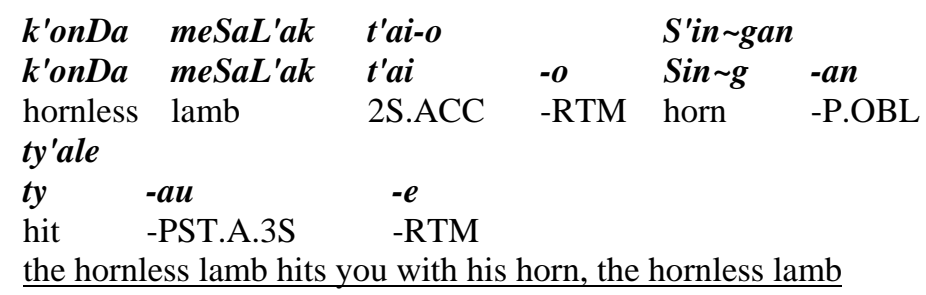

the hornless lamb hits you with his horn, the hornless lamb

\begin{tabular}{|c|c|c|c|c|c|}
\hline $\begin{array}{l}\boldsymbol{k}^{\prime} \text { onDa } \\
\boldsymbol{k}^{\prime} \text { 'onDa } \\
\text { hornless }\end{array}$ & $\begin{array}{l}\text { meSaL'ako } \\
\text { meSaL'ak } \\
\text { lamb }\end{array}$ & $\begin{array}{l}-o \\
\text {-RTM }\end{array}$ & $\begin{array}{l}\boldsymbol{s e} \\
\boldsymbol{s e} \\
\text { REM.S.NOM }\end{array}$ & $\begin{array}{l}\text { nash'a } \\
\text { nash'a } \\
\text { inebriated }\end{array}$ & $\begin{array}{l}\boldsymbol{t i} \\
\boldsymbol{t i} \\
\text { become.CP }\end{array}$ \\
\hline $\begin{array}{l}\text { kas-i } \\
\text { walk-CP }\end{array}$ & $\begin{array}{l}-\boldsymbol{o} \\
\text {-RTN }\end{array}$ & & & & \\
\hline
\end{tabular}

the hornless lamb walks around drunk

$\begin{array}{lllll}\text { k'onDa } & \text { meSaL'ak } & a m \text { 'E a } & \text { got } & \text { meSaL'ak } \\ \text { k'onDa } & \text { meSaL'ak } & \text { am'E a } & \text { got } & \text { meSaL'ak } \\ \text { hornless } & \text { lamb } & \text { sheep } & \text { crazy } & \text { lamb }\end{array}$

the hornless lamb, crazy for a sheep

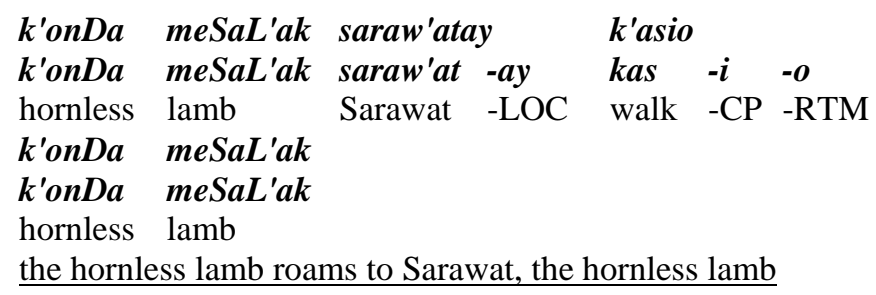




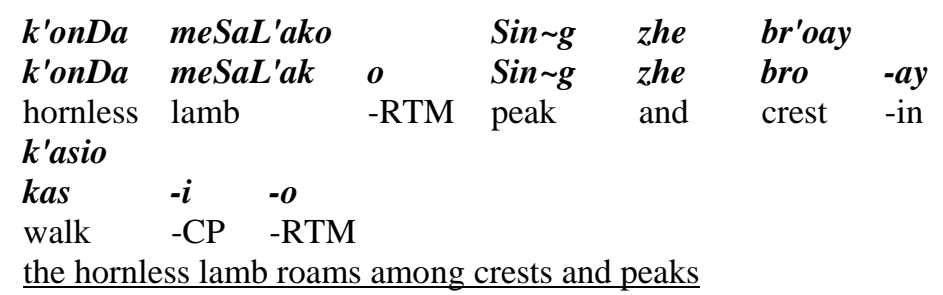




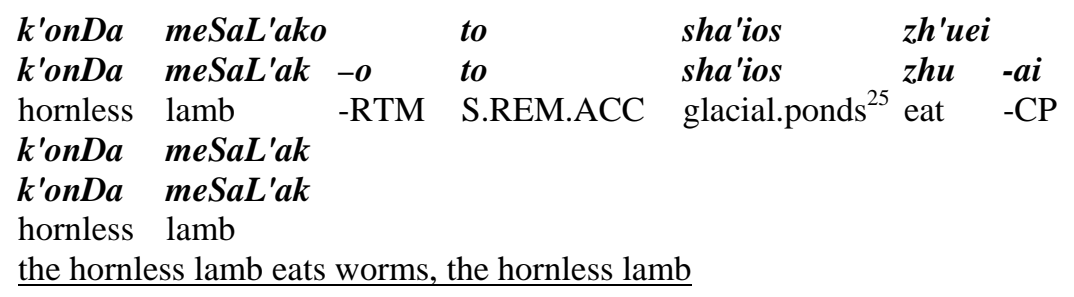

$\begin{array}{lllll}\text { k'onDa meSaL'ak } & \text { s'aras } & \text { pres } & \text { c'arila } \\ \text { k'onDa meSaL'ak } & \text { s'aras pres } & \text { car } & \text {-ila } \\ \text { hornless lamb } & \text { juniper branches } & \text { graze } & \text {-PST.HRS } \\ \text { k'onDa meSaL'ak } & & & \\ \text { k'onDa meSaL'ak } & & & \\ \text { hornless lamb } \\ \text { the hornless lamb grazes on the lower branches of the juniper trees, the } \\ \text { hornless lamb }\end{array}$

"The hornless ram hits you with his horn" was the refrain repeated after each verse (not transcribed here for the sake of brevity). The sentence contains an apparent contradiction that was unravelled at the moment of the translation of the text, when it was explained to me that the horn was a metaphorical one, representing the male organ. meSaL'ak is a ram aged between one year and one year and half, that can therefore easily be still without horns. The chant evokes thus the image of a young ram, madly in search of a female, in a state of exhilaration (nash'a ti), roaming the high peaks among the mountain spirits (s'uci), dancing in the snow and grazing on mountain grass and juniper buds, ready to hit anyone with his male organ. An image of male virility, it seems, represented as bursting out of the 'onjiSTa sphere of the high mountains. An image containing the three most apparent traits of the realm of the 'pure': it is male, it is pastoral, it is connected to wild nature. ${ }^{26}$ The reference to Sarawat is of some importance. It is the name of a remote mountain pasture that plays a

25 The reference is, I was told, to the worms found in glacial ponds: the grass soaked in snow produces worms, on which the herds feed. The term used in the verse for glacial pond is Khowar; the Kalasha word is p'utsas.

26 It is interesting to note that in a Vedic hymn Indra is represented as a famous ram (De Gubernatis 1872: 403): it could be that the hornless ram of the song is none other than Indra. 
role in the mythology, because it is the place where the dough figurines made for Lagaur are believed to be led during the night by their walm'oc, their shepherd, a majestic dough markhor to whom a special place is reserved on the main beam (sat'ar) of the house; the animals are then taken into custody by the fairies (s'uci), which indicates that they are seen as an offering to the mountain spirits. Sarawat, where - I was told - there is a spring and a lake, is deemed to be their abode and represents therefore the very core of 'onjiSTa territory in the Birir valley.

The lyrics of two different chants appear in fact to have been conflated in this text. One is the chant of the 'hornless ram', the other is a chant the same man sang immediately after, on a different melody, called mai muzh'ik, my markhor kid, which missed the refrain but had for the rest very similar verses. It may be that the former was imported from the two northern valleys because it is closely connected to the Balimain cult (cf. Wutt 1983: 116), ${ }^{27}$ while the latter is a song of Lagaur celebrating the markhor that leads the goats to Sarawat. The verses "leads the pure herd" and "roams to Sarawat" surely belong to this second one.

\section{Text no.15}

While the time of Chaumos is indicated by the movement of the sun, the time of the festivities that follow is regulated by the lunar cycle. Between the fifth and the seventh day of the January moon, about two weeks after Lagaur - from the $23^{\text {rd }}$ to the $25^{\text {th }}$ of January in $2007-$ Jhanì was celebrated. The event concerned in fact only little girls (and their female relatives), while the male population appeared to ignore it altogether and to hardly consider it a festival. For the girls, however, the celebration brought three days of fairly intense activities. On the first day they conducted a ritual begging collecting beans and flour: while on the last day of Chaumos ( $d A^{\prime} u$ tat'u), the begging was carried out at the village level, for Jhanì the girls made the round of all the villages of the moiety they belonged to. In the evening the foodstuffs collected were brought to the temple of Guru where - like for the

27 One of my assistants asserted that it is chanted in Birir on the morning of the day of initiations (ist'on gas rat), but I do not remember hearing it on that day. 
'feast of beans' - young people gathered until late at night singing and dancing, while a few adolescent girls watched over the pots boiling under the porch; the following day the cooked food was distributed to all the families, to be eaten only by women. The third day the ceremony of the purification of dolls took place. These consist of a wooden skeleton in the shape of a cross on which a tailored little dress is fitted. They are made by the parents as a gift to their daughters. The little girls, with the help of their mothers, are supposed to bake bread for them. The rite did not amount to much: there was no fumigation with juniper as in women's purification rites, and once the bread cakes were ready, the girls grabbed their dolls and ran out of the house. The ceremony, at any rate, is meant to introduce them to the basic feminine tasks, making bread, fetching water and taking care of babies. Though not formally considered part of the initiation rituals, Jhanì seems therefore to have an initiatory character. It announces indeed an impending change of status and it gives the little girls a first glimpse of their future life as wives and mothers. A future life not free of sorrow, as testified by the song transcribed below. Its text was not recorded, but was dictated to me by a middle-aged man who maintained it was that of an old song, forgotten by the women.

\begin{tabular}{|c|c|c|c|c|c|}
\hline tu & ta & mai & kAmbAh'uki & k'ari & \\
\hline tu & ta & $m^{\prime} a i$ & kAmbAh'uki & kar & $-i$ \\
\hline $\begin{array}{l}\text { 2S.NOM } \\
\text { aо }\end{array}$ & CORR & $\begin{array}{l}\text { 1S.OBL } \\
\boldsymbol{t}^{\prime} \boldsymbol{a i}\end{array}$ & $\begin{array}{l}\text { doll } \\
\text { khazin'a }\end{array}$ & $\begin{array}{l}\text { make } \\
\text { pash'em }\end{array}$ & P/F.2S \\
\hline$a$ & -0 & $t^{\prime} a i$ & khazin'a & pash & $-e m$ \\
\hline 1S.NOM & -CORR & 2S.DAT & treasure & see.CAUS.P. & $1 \mathrm{~S}$ \\
\hline
\end{tabular}

\begin{tabular}{|c|c|c|c|c|c|}
\hline $\begin{array}{l}\text { khoy } \\
\text { khoy }\end{array}$ & ta & $\begin{array}{l}\text { aug'an } \\
\text { aug'an }\end{array}$ & $\begin{array}{l}\text { desh } \\
\text { desh }\end{array}$ & $\begin{array}{l}\text { mai } \\
m^{\prime} a i\end{array}$ & $\begin{array}{l}\text { de } \\
\text { de }\end{array}$ \\
\hline $\begin{array}{l}\text { or } \\
\text { mai }\end{array}$ & $\begin{array}{l}\text { CORR } \\
\text { d'adako }\end{array}$ & Afghan & country & 1S.ACC & give.IMPV.2S \\
\hline m'ai & d'ada & $-k o$ & & & \\
\hline 1S.GEN & father & $-E$ & & & \\
\hline
\end{tabular}

either you give me away in the land of the Afghans, my dear father 


\begin{tabular}{lllll}
$\boldsymbol{k} \boldsymbol{O}^{\prime}$ A & shak & \multicolumn{1}{c}{ amish'oti } & k'arim & \\
kO'A & shak & amish'oti & kar & -im \\
koa & vegetables & salt.mix & make & -P/F.1S \\
\multicolumn{2}{l}{ and I will cook vegetables with salt } & &
\end{tabular}

and I will cook vegetables with salt

\begin{tabular}{|c|c|c|c|c|c|}
\hline $\begin{array}{l}\text { khoyo } \\
\text { khoy }\end{array}$ & -0 & $\begin{array}{l}\text { kushtyagr'om } \\
\text { kushtyagr'om }\end{array}$ & $\begin{array}{l}k^{\prime} u i \\
k^{\prime} u i\end{array}$ & $\begin{array}{l}\text { mai } \\
\text { m'ai }\end{array}$ & $\begin{array}{l}\text { de } \\
\text { de }\end{array}$ \\
\hline or & -CORR & Kamdesh & valley & 1S.ACC & give.IMPV.2S \\
\hline
\end{tabular}

or you give me away in the Bashgal valley

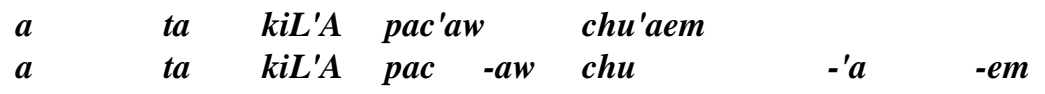

1S.NOM TOP cheese cook -AGT dip.bread.in.food-CAUS -P/F.1S and I will prepare cheese

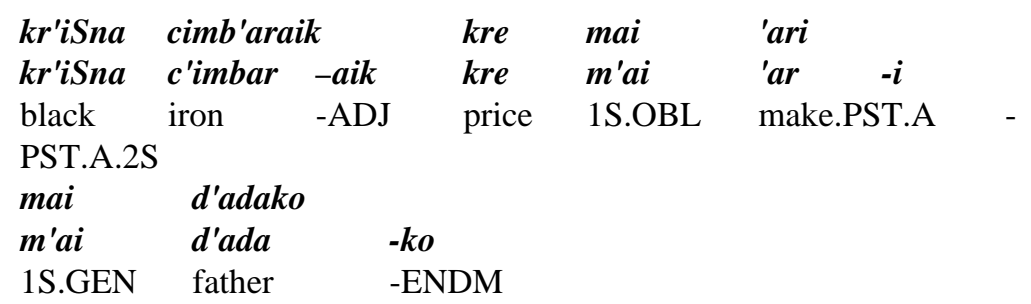

you gave me away in exchange for dark iron, my dear father

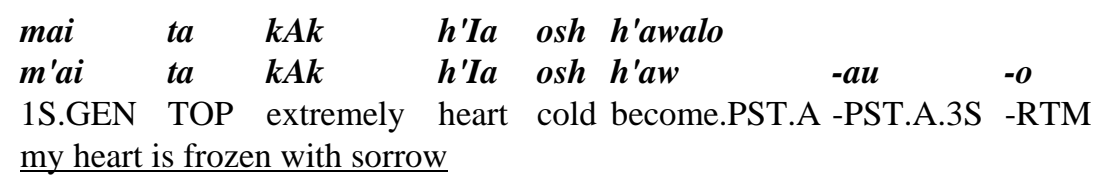

In the song a girl addresses her father saying that he makes a doll for her, but she will give him a treasure; a quite clear reference to the bride-price he will receive when he'll give her in marriage. "You will give me away in exchange for iron," she adds, referring to the tripods and the cauldrons for making cheese that customarily compose it. She fears especially to be given to a foreigner and her heart, she says, is frozen with grief.

kushti' $a$ is the name given by the people of Birir to the Kom of the neighbouring Bashgal valley, in Afghan Nuristan. A marriage between a Kom man and a Kalasha girl may have been a possibility before the Kom were forcibly converted to Islam at the end of the nineteenth 
century. ${ }^{28}$ In contrast, a marriage to a Pashtun - this is what is intended by "Afghan" - seems hard to imagine, because these people have been Muslims for a long time. It could be, however, that there were times when a Kalasha father in dire straits would sell his daughter outright, under the feeble disguise of a marriage, to a Muslim man who would of course convert her.

We have here one more song expressing the suffering of Kalasha girls when they are married still children to a man who will take them away from their family and friends, if not from the whole community; as it is feared by the girl in the case she is given to a foreigner.

\section{Text no. 16}

Though Chaumos has all the characteristics of a New Year festival, the beginning of the new year is not marked by the solstice. The new cycle begins in fact in the following lunar month, when the moon is full, with an animal sacrifice celebrated at one of the main shrines.

A New Year celebration at the end of January is not surprising, because in the Indo-European world the date of the beginning of the year, though quite variable, remains generally included between December and March (Dumézil 1929: 6-10; cf. Propp 1978: 44-45; Van Gennep 1988: 3471-3472). From the name of the sacrifice b'asun don, 'spring bullock' - and for the fact that it is celebrated at the end of the coldest period, the New Year day of Birir seems to be connected to the spring, rather than to the winter, season. This was the trend prevailing in ancient Persia. An influence from the Iranian world seems to be indeed indicated by the name itself of the Birir celebration, which is called salgher'ek: while gher'ek is a Kalasha term meaning 'rotate', sal is the Persian term for 'year', which I never recorded in Birir in any other instance.

The sacrifice of b'asun don that celebrates the 'rotation' of the year is performed at the shrine of the god Mahandeo. In 2007 the sacrificial victim, however, was not a bullock, as the name of the ritual would seem to imply, but a kid. What follows is the text of the 
prayer that accompanied the central part of the rite, recorded at the Mahandeo shrine on January $31^{\text {st }}$.

$\begin{array}{lll}\boldsymbol{e} & \text { all'ah } & \text { parwadig'ar } \\ \boldsymbol{e} & \text { all'ah } & \text { parwadig'ar } \\ \mathrm{O} & \text { Allah } & \text { Creator.God }\end{array}$

$\underline{\text { O Allah Creator }}$

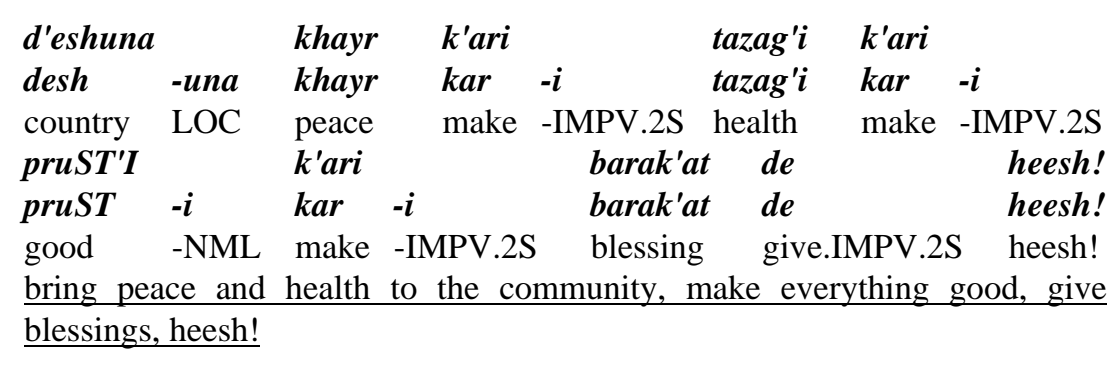

$\begin{array}{llll}\boldsymbol{e} & \text { all'ah } & \text { pak } & \text { parwadig'ar } \\ \boldsymbol{e} & \text { all'ah } & \text { pak } & \text { parwadig'ar } \\ \text { O } & \text { Allah } & \text { holy } & \text { Creator.God }\end{array}$

$\underline{\text { O Allah, holy Creator }}$

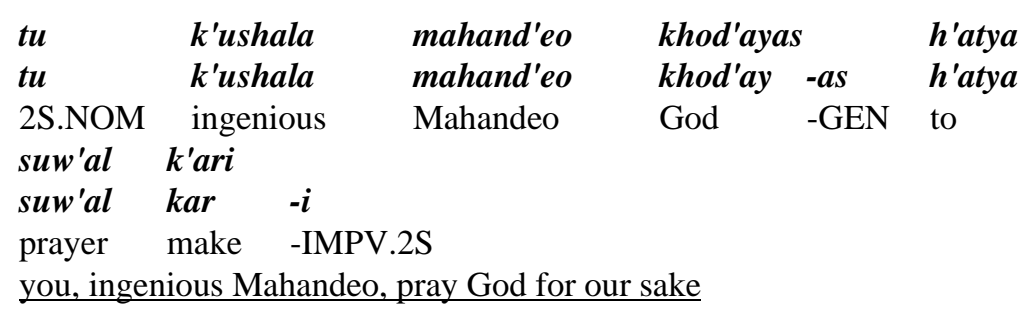

\begin{tabular}{|c|c|c|c|c|c|c|c|}
\hline $\begin{array}{l}\text { mun } \\
\text { mund }\end{array}$ & & $\begin{array}{l}\text { pili'ai } \\
\text { pili }\end{array}$ & $-a i$ & $\begin{array}{l}\text { m'undo } \\
\text { munD }\end{array}$ & $-o$ & $\begin{array}{l}\text { uchund'ai } \\
\text { uchund -c }\end{array}$ & $\begin{array}{rr} & \text { heesh! } \\
\text {-ai } & \text { heesh! }\end{array}$ \\
\hline & CORR & climb & $-\mathrm{CP}$ & top & -CORR & descend - & -CP heesh! \\
\hline
\end{tabular}

As in other prayers we commented, we find here the Kalasha god represented as an intermediary between humans and the Creator God, in line with the monotheistic reinterpretation of Kalasha religion which, as we have seen, is now quite firmly established. The requests are the usual ones, of peace and good health. The peculiarity of this 
prayer lies in the cry heesh! which I had not heard before, and in the last verse, for which I could obtain no explanation. It is in all likelihood a traditional formula referring, it would seem, to the end of a cycle and the beginning of a new one. A formulation, that is, of the idea of cyclical time: once the end, the top, or if we want, the climax, has been reached, you can only descend and start over again. The 'rotation' of the year had been celebrated.

\section{Text no.17}

The same evening a final ritual was celebrated in all households, dedicated this time to the goddess Jeshtak, who presides over the domestic world of the family. A mash of walnuts and cheese with wheat bread was the ritual meal. The prayer below was recorded in the home of one of my hosts, who recited it personally.

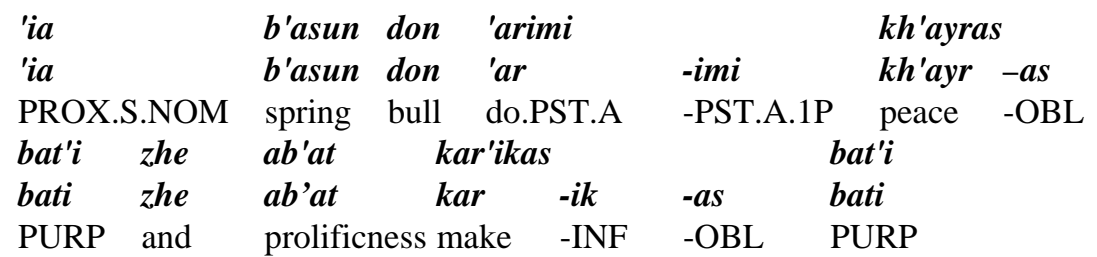

we have done this basun don ritual for the sake of peace and abundance of children

$\begin{array}{llll}\text { 'ama } & \text { ishper'i } & \text { k'arik } & \text { day } \\ \text { 'ama } & \text { ishper'i } & \text { kar }-i k & \text { d'ay }\end{array}$

PROX.S.ACC ritual.meal make -P/F.1P P/F.CONT

now we are having this ritual meal

\begin{tabular}{|c|c|c|c|c|c|c|c|}
\hline se & tu & d'uray & & j'eSTak & zhe & baS & zhu'aw \\
\hline se & tu & dur & $-a y$ & j'eSTak & zhe & baS & zhu'aw \\
\hline $\mathrm{HON}$ & 2S.NOM & house & -of & Jeshtak & and & share & eater \\
\hline khayr & k'ari & & & & & & \\
\hline khayr & kar & \multirow{2}{*}{\multicolumn{6}{|c|}{$\begin{array}{l}-\boldsymbol{i} \\
\text {-IMPV 2S }\end{array}$}} \\
\hline peace & make & & & & & & \\
\hline
\end{tabular}




$\begin{array}{llllll}\text { Chek } & \text { Chom'iko } & & \text { d'esha } & \text { h'isti } & \\ \text { Chek } & \text { Chom'ik } & \text {-o } & \text { d'esha } & \text { hist } & \text {-i } \\ \text { trouble } & \text { pain } & \text {-SEQ } & \text { far } & \text { throw } & \text {-IMPV.2S }\end{array}$

keep trouble and pain away from us

The deity is called goddess of the home because her emblem - two little wooden horse-heads protruding from a small wooden plank -is usually found in Birir in every house and, of course, because she presides over family relations. She is also addressed as 'share eater', an epithet given to all gods because in sacrifices they are given a part of the body of the victim - mostly the blood - and they share thus the sacrificial meal with men. The requests are again the usual ones, but the rite has nevertheless a special significance because, once it is completed, the prohibition over the consumption of the fruits of the last harvests is lifted: the sacred meal of that evening was indeed made with flour and walnuts from the autumn harvests. From that moment on, all the products of the cycle just concluded, could be consumed.

With that rite the old year was finally dismissed, and the new one was hailed in. The following day - the day of benjisht'em - was going to be the very first of the New Year. It was celebrated with a meal of squash in the morning, fertility rites at the goat-sheds, and a ritual meal in the evening.

\section{Appendix: Outline and chronology of the winter ritual celebra- tions in Birir in 2006-07}

Preparations for Chaumos

acar'ik - gandalik'an - 10 December 2006

- virgin boys make preparations at the shrine of the god Praba

- old baskets are burnt and Chaumos songs and dances are sung around the bonfires

Chaumos - 14 - 20 December 2006

desh suc'ein - 14 December

- purification of the territory with juniper smoke 
ruzh'ias - 15 December

- cleaning of the houses

- animal sacrifices for the first wine of the year

- offerings to the dead

goST-s'araz - 16 December

- purification rites with juniper smoke at the goat-sheds

- processions/assaults with torches to the temples: the young and the novices insult the elderly

- songs and dances in the temple until late at night

non g-rat - 17 December

- ritual begging of the novices

- beginning of initiation sacrifices

- purification rites in the homes for female novices

- washing of kitchen implements, which are not to be touched until the early morning rite (see below)

- evening fast

- rite with offerings of rice and juniper smoke just before the break of dawn

ist'on gas-rat - 18 December

- offerings to the dead brought by young girls

- novices are dressed with ceremonial clothes in the homes by the maternal uncle, and are brought to the temple

- male initiation rites at the goat-sheds with animal sacrifices

- beginning of seclusion for the novices

- banquets with meat and wine offered in the goat-sheds by the families of the novices to all the male members of each moiety

- holocaust at the break of dawn at the shrine of the god Praba, with the participation of the novices

- singing and dancing in the temples and torchlight procession in the early hours of the morning (3:00 a.m.): each of the two moieties is reunited in one of the temples

koT SaT'ek - 19 December

- the whole community gathers in full daylight for a whole day of singing and dancing

- ritual game of the capture of the fortress (nog'or grik)

- ritual chasing away of the fox (Law'ak bih'ik)

- running competition and lighting of a fire (koT SaT'ek) 
- fight and general commotion

- rite with mistletoe and secret prayer

- concluding dance led by man with mistletoe, called the dance of the markhor (sharacat'aki)

dA'u tat'u - 20 December

- dancing and singing in full daylight outside one of the temples

- ritual begging of beans by young girls

- rite with mistletoe marks the end of the seclusion of the novices

- young people gather in the temple to oversee the cooking of the beans.

\section{After Chaumos}

dah'u pac'ein - 21 December

- the cooked beans are distributed in the homes

SiS khur -6 days later

- the heads and the legs of sacrificed animals are eaten

Lagaur - 3-9 January 2007

First day

- the kazi announce the beginning of the festival

- ritual meal with cheese in the evening

Second day

- in the evening ritual meal with beans and walnuts

Third day

- in the morning the women make animal figures with bread dough

- children of both sexes go to the goat-shed area singing the song of the Crow, and they collect leafy branches to decorate the temples.

- in the evening the men make animal figures stuffed with walnut mash mostly representing markhors, and a large bread cake to take to the goat-sheds early the following morning. 
Fourth day

- women gather in the temple two hours before dawn to invoke the White Crow

- when they are finished, the men take the large bread-cake to the goat-sheds.

- in the villages children imitate the rituals of Chaumos.

Six days of dances for children follow (reduced to two in 2007)

Last day

- game in which the children imitate the ritual race of the central day of Chaumos

- boys take the dough figurines made by the men up to a small plateau above Guru village and leave them there for the crows

- the bread figurines made by the women are given to the goats.

Jhanì - 23 - 25 January 2007

First day

- ritual begging of flour and beans by little girls who make the round of the villages of each moiety

- cooking of the beans in the temple and gathering of young people

Second day

- distribution of the cooked food to all the families of the village (only for female members)

Third day

- ritual purification of the dolls

Salgherek - 31 January 2007

- in the morning animal sacrifice at the shrine of the god Mahandeo

- in the evening, rite in the homes in honour of the goddess Jeshtak, which marks the lifting of the ban over the consumption of the fruits of the last harvests.

Benjishtem - 1 February 2007 - first day of new year

- in the morning breakfast with squash

- fertility rites at the goat-sheds

- in the evening, ritual meal with cheese and walnut mash at the goat-sheds 


\section{References}

BASHIR, E. (1988), Topics in Kalasha Syntax: An Areal and Typological Perspective. Ph.D. Dissertation. University of Michigan. Ann Arbor.

BASHIR, E. (2003), Dardic. In: Cardona, G. \& Dh. Jain (eds.), The Indo-Aryan Languages. Routledge. London.

BASHIR, E. \& Israr-ud-Din (1996) (eds.), Proceedings of the Second International Hindukush Cultural Conference. Oxford University Press. Karachi.

Bell, C. (1997), Ritual. Perspectives and Dimensions. Oxford University Press. New York \& Oxford.

CACOPARDO, A. M. (1991), The Other Kalasha. A Survey of Kalashamun-Speaking People in Southern Chitral. Part I: The Eastern Area. East \& West. 41, 1/4, pp. 273-310.

CAcopardo, A. M. (1996), The Kalasha in Southern Chitral. Part I: The Eastern Area. In: Bashir \& Israr-ud-Din (1996).

CAcopardo, A. M. \& A. S. Cacopardo (1989), The Kalasha (Pakistan) Winter Solstice Festival. Ethnology. 28, 4, pp. 317329.

CAcopardo, A. M. \& A. S. Cacopardo (1992), The Other Kalasha. A Survey of Kalashamun-Speaking People in Southern Chitral. Part III: Jinjeret Kuh and the Problem of Kalasha Origins. East \& West. 42, 2/4, pp. 333-375.

CACOPARDO, A. M. \& A. S. Cacopardo (1996), The Kalasha in Southern Chitral. Part III: Jinjiret Kuh and the Problem of Kalasha Origins. In: Bashir \& Israr-ud-Din (1996).

CAcopardo, A. M. \& A. S. Cacopardo (2001), Gates of Peristan. History, Religion and Society in the Hindu Kush. Is.I.A.O. Roma. 
CACOPARDO, A. S. (1985), Chaumos: la festa del solstizio d'inverno. L'Universo. 65, 6, pp. 724-753.

CACOPARDO, A. S. (1991), The Other Kalasha. A Survey of Kalashamun-Speaking People in Southern Chitral. Part II: The Kalasha of Urtsun. East \& West. 41, 1/4, pp. 311-350.

CAcopardo, A. S. (1996), The Kalasha in Southern Chitral. Part II. The Pre-Islamic Culture of the Urtsun Valley. In: Bashir \& Israrud-Din (1996).

CACOPARDO, A. S. (2006), Anthropomorphic Representations of Divinities among the Kalasha of Chitral (Pakistan). Acta Orientalia, 67, pp. 127-158. Oslo.

CAcopardo, A. S. (2008), The Winter Solstice Festival of the Kalasha of Birir: Some Comparative Suggestions. Acta Orientalia, 69, pp. 77-120. Oslo.

CACOPARDO, A. S. (2010), Natale pagano. Feste d'inverno nello Hindu Kush. Sellerio. Palermo.

CAILlOIS, R. (2001), Man and the Sacred. University of Illinois Press. Urbana and Chicago. Or. ed. L'homme et le sacré, Gallimard. Paris 1939.

DECKER, K. D. (1992), Languages of Chitral. Sociolinguistic Survey of Northern Pakistan (5 vols). Vol. 5. National Institute of Pakistan Studies and Summer Institute of Linguistics. Islamabad.

De Gubernatis, A. (1872), Zoological Mythology. 2 vols.,Trubner \& Co. London.

Di CARLO, P. (2007), The Prun Festival of the Birir Valley, Northern Pakistan, in 2006. East \& West, 57, 1-4, pp. 45-100.

DI CARLO, P. (2009), I Kalasha del Hindu-Kush: ricerche linguistiche e antropologiche. Ph.D. Dissertation. University of Florence. 
Di CARLO, P. (2010), Two clues of a former Hindu Kush linguistic area? Everhand, C. \& E. Mela-Athanasopoulou (eds), International Conference on Language Documentation and Tradition with special interest in the Kalasha of the Hindu Kush Valleys, Himalayas. Selected Papers. University Studio Press. Thessaloniki, pp 88-104.

DumÉZIL, G. (1929), Le problème des Céntaures. Librairie orientaliste Paul Geuthner. Paris.

EliAdE, M. (1976), Trattato di storia delle religioni. Boringhieri. Torino. Or. ed. Traité d'histoire des religions. Payot. Paris 1948.

HEEgÅRD, J. (2006), Local Case Marking in Kalasha. Ph.D. Dissertation. University of Copenhagen.

HEEGÅRD, J. \& I. E. Mørch (2004), Retroflex vowels and other peculiarities in the Kalasha sound system. In Saxena, A. (ed.), Himalayan Languages. Past and Present. Mouton de Gruyter. Berlin and New York.

JetTMAR, K. (1975), Die Religionen des Hindukush. Die Religionen der Menscheit. Vol. 4, 1. Verlag W. Kohlhammer. Stuttgart.

LANTERNARI, V. (1983), La grande festa. Dedalo. Bari. Or. ed. Bari 1976.

LIEVRE, V. \& J.-Y. Loude (1990), Le chamanisme des Kalash du Pakistan. Presses Universitaires de Lyon. Lyon.

LIEVRE, V. \& J.-Y. Loude (1991), Le vin du ciel. L'univers du vivant. 34, pp. 16-37.

LiNES, M. (1988), Beyond the North-West Frontier. The Oxford Illustrated Press. Sparkford.

LOUDE, J.-Y. (1980), Kalash. Paris.

LOUdE, J.-Y. \& V. Lièvre (1984), Solstice païen. Presses de la Renaissance. Paris. 
LOUDE, J.-Y. \& V. Lièvre (1988), Fètes d'été chez les Kalash du Nord-Pakistan: cascades de lait, vin de jambes et berger géniteur. L'Ethnographie. 83, 100/101, pp. 191-220.

MAGGI, W. (2001), Our Women are Free. Gender and Ethnicity in the Hindu Kush. The University of Michigan Press. Ann Arbor.

MASICA, C.F. (1991), The Indo-Aryan Languages. Cambridge University Press. Cambridge.

MAuss, M. (1965), Saggio sul dono. In Teoria generale della magia e altri saggi. Einaudi. Torino. Or. ed. L’Année Sociologique 1923-24.

MøRCH, I.E. (2000), How fast will a language die when it is officially no longer spoken? Odense Working Papers in Language and Communication, 19, II. University of Southern Denmark. Odense.

Morgenstierne, G. (1947), The Spring Festival of the Kalash Kafirs. In: India Antiqua. A Volume of Oriental Studies Presented to J. P. Vogel, pp. 240-48. Leyden.

Morgenstierne, G. (1973), Indo-Iranian Frontier Languages. The Kalasha Language.Vol. 4. Institute for Comparative Research in Human Culture. Oslo.

PARKES, P. (1983), Alliance and Elopment: Economy, Social Order and Sexual Antagonism among the Kalasha (Kalash Kafirs) of Chitral. Ph.D. Dissertation. Oxford University.

PARKES, P. (1994), Personal and Collective Identity in Kalasha Song Performance: The Significance of Music-Making in a Minority Enclave. In: Stokes, M., (ed.), Ethnicity, Identity and Music, pp. 157-87. Berg. Oxford/Providence, USA.

PARKeS, P. (1996), Kalasha Oral Literature and Praise Songs. In Bashir \& Israr-ud-din (1996), pp. 315-328. 
Propp, V. (1978), Feste agrarie russe. Dedalo. Bari. Or. ed. Leningrad 1963.

SAIFULLAH JAN (1996), History and Development of the Kalasha. In: Bashir \& Israr-ud-Din (1996), pp. 239-245.

SCHOMBERG, R. C. F. (1938), Kafirs and Glaciers, Travels in Chitral. London.

SIIGER, H. (1956), Ethnological Field Research in Chitral, Sikkim and Assam. Det Kongelige Danske Videnskabernes Selskab. 35, 2, pp. 5-35.

SNOY, P. (2008), The Rites of the Winter Solstice among the Kalash of Bumburet. In Journal of Asian Civilizations, XXXI, 1-2, pp. 36-64. Islamabad.

StAley, J. (1964), The Pool Festival of the Kalash of Birir. Folklore. 74, pp. 197-202.

Staley, J. (1982), Words for My Brother. Oxford University Press. Karachi.

Trail, R. L. \& G. R. Cooper (1999), Kalasha Dictionary. Summer Institute of Linguistics and National Institute of Pakistan Studies. Islamabad.

TURNeR, R. L. (1966), A Comparative Dictionary of the Indo-Aryan Languages. Oxford University Press. London.

VAn GenneP, A (1981), I riti di passaggio. Boringhieri. Torino. Or. ed. Les rites de passage. Emile Nourry. Paris 1909.

VAN GENNEP, A. (1988), Manuel de folklore français contemporain. Cycle des douze jours: de Noël aux Rois.Vol. 8, 1. Picard. Paris. 
Witzel, M. (2004), The Rgvedic Religious System and its Central Asian and Hindukush Antecedents. In: Griffiths, A. and J. E. M. Houben (eds.), The Vedas: Texts, Language \& Ritual. Proceedings of the Third International Vedic Workshop, Leiden 2002. Egbert Forsten, Groningen, pp. 581-636.

WUTT, K. (1983) Chaumos = "Vier Mal Fleisch": Notizen zum Winterlichen Festkalender der Kalash von Bumburet, Chitral. Archiv für Völkerkunde. 37, pp. 107-48.

\section{Note on the Transcriptions and Abbreviations Used in the Texts}

Capital letters express a retroflex articulation which in Kalasha occurs not only in consonants but also in vowels (Heegård \& Mørch 2004; Di Carlo 2010). $<$ sh $>$ represents the voiceless palatal sibilant, $<$ zh $>$ its voiced counterpart; but all other consonants followed by $<\mathrm{h}>$ are to be pronounced as aspirates; $<\mathrm{y}>$ represents the palatal approximant and $\langle\mathrm{w}\rangle$ the voiced labio-velar approximant. All the other phones are transcribed according to Masica's 'Standard Orientalist' transcription (Masica 1991: XV-XVI), including the palatal affricate expressed with $\langle\mathrm{c}\rangle$. Since Kalasha syllabification is not as yet thoroughly studied, stress is marked by the symbol $<$ ' $>$ in front of the stressed vowel, and not, as in IPA, in front of the stressed syllable. Nasalization is expressed by $<\sim>$ following the nasalized letter.

\section{Abbreviations}

ACC: Accusative Case

ADJ: Adjectivizer

AGT: Agent

AN: Animate

CAUS: Causative

CORR: Correlative

CP: Conjunctive Participle

DIR: Direct Case

DMN: Diminutive 
DIST: Distal

ECO: Eco-words

ENDM: Endearment

GEN: Genitive Case

HUM: Humoristic

IMPV: Imperative

INAN: Inanimate

INT: Intensifier

LOC: Locative

NEG: Negation

NML: Nominalizer

NOM: Nominative Case

OBL: Oblique Case

P: Plural

P/F: Present Future

P/F CONT : Present Future Continuous

PCL: Particle

POSS: Possessive (suffixes)

PRF.P Perfect Participle

PROX: Proximal

PST.A: Past Actual

PST.HRS: Hearsay Past

PURP: Purpose

REM: Remote

RTM: Rhythmical Element

S: Singular

SEQ: Sequencer

TOP: Topical

VIA: Vialis

VIS: Visible 